This item was submitted to Loughborough's Research Repository by the author.

Items in Figshare are protected by copyright, with all rights reserved, unless otherwise indicated.

\title{
Factors affecting environmental practice adoption at small European airports: an investigation
}

PLEASE CITE THE PUBLISHED VERSION

https://doi.org/10.1016/j.trd.2020.102572

PUBLISHER

Elsevier

VERSION

AM (Accepted Manuscript)

PUBLISHER STATEMENT

This paper was accepted for publication in the journal Transportation Research Part D: Transport and Environment and the definitive published version is available at https://doi.org/10.1016/j.trd.2020.102572.

LICENCE

CC BY-NC-ND 4.0

\section{REPOSITORY RECORD}

Crowley, Grace, Andrew Timmis, and Lucy Budd. 2020. "Factors Affecting Environmental Practice Adoption at Small European Airports: An Investigation”. Loughborough University.

https://hdl.handle.net/2134/13582661.v1. 


\title{
Factors affecting environmental practice adoption at small European airports: an investigation
}

Grace Harley ${ }^{1}$, Andrew Timmis $^{1}$ and Lucy Budd ${ }^{2}$

\author{
${ }^{1}$ Transport Studies Group, School of Architecture, Building and Civil Engineering, Loughborough \\ University, Loughborough, Leicestershire, UK, LE11 3TU. \\ ${ }^{2}$ Leicester Castle Business School, De Montfort University, Leicester, LE1 9BH, UK \\ Corresponding author: lucy.budd@dmu.ac.uk
}

\section{Please cite as:}

Harley, G., Timmis, A., Budd, L. (2020) Factors affecting environmental practice adoption at small European Airports: an investigation. Transportation Research Part D: Transport and Environment, 88, 102572. 


\section{Factors affecting environmental practice adoption at small European airports: an investigation}

Keywords: environmental practices; small airports; determinant factors; air transport; TOE framework; Europe.

\section{Abstract}

The majority of the world's 3,759 commercial airports handle under 5 million passengers a year and these small airports rarely employ practices to address their environmental externalities. The aim of this research is to investigate the range of environmental practices (EPs) that are employed at small European airports and identify the factors which affect their adoption. The findings of an online survey of 413 small airports in the European Common Aviation Area reveal that the EPs most commonly adopted concern waste management and noise reduction. Privately owned airports were generally more engaged with EPs than publicly owned ones. Consumer pressure, regulatory intervention, and airport size positively affected the adoption of environmental practices whereas complexity, perceived relative advantage and human resource constraints acted as barriers to adoption. The paper concludes with recommendations for policy and practice to support EP engagement and reduce the environmental impact of small airport operations worldwide.

\section{Introduction}

Prior to the COVID-19 global pandemic, airports facilitated the worldwide transportation of over 4.4 billion passengers and 62 million tonnes of airfreight each year and generated \$2.7 trillion in global economic activity (ATAG, 2018). Commercial aviation activities generate significant global and local 
environmental externality effects. By 2040, aviation related $\mathrm{NO}_{x}$ and $\mathrm{CO}_{2}$ emissions are predicted to increase by $16 \%$ and $21 \%$ respectively (Aviation Environment Federation, 2016; CAA, 2017; EASA, 2019) and tens of millions of residents of local airport communities are exposed to levels of aircraft noise that exceed WHO recommended thresholds. The global air transport industry is coming under increased political and consumer pressure to reconcile global demand for flight with commitments to improve its environmental performance (ACl-Europe, 2009b). Although aircraft emissions have been the focus of systematic academic research since the 1950s, it is only more recently that the need to address airports' wide-ranging environmental impacts, which include 'noise pollution, energy consumption, water pollution, waste management, and the storage and control of hazardous materials' (Boiral et al., 2017, p. 1), has begun to be recognised.

An airport's negative environmental externalities arise as a result of both airside and landside operations. Many are the result of third-party operations (e.g. aircraft noise and local air pollution) which are facilitated by the airport operator. Despite airport operators having little direct ownership of many of the sources of environmental impacts within the airport system, they have a unique role in their management and a significant role in affecting change (for example by setting operational procedures and targets).

Many large airports have recognised the incompatibility of future operations with the principles of sustainability and have adopted mitigating actions in the form of sustainability programmes. London Heathrow's 'Heathrow 2.0' strategy and Hartsfield-Jackson Atlanta International's 'GreeningATL' are examples of how large airports are embedding environmental practices (EPs) in their operations (Your Heathrow, 2018; Hartsfield-Jackson Atlanta International Airport, 2019). In this context, EPs are defined as 'techniques, policies and procedures a firm uses that are specifically aimed at monitoring and controlling the impact of its operations on the natural environment' (Montabon et al, 2007, p. 998). Examples of EPs which can be employed at airport sites include, but are not limited to, practices which reduce noise pollution, such as imposing noise preferential routes (NPRs,) 
continuous descent operations (CDOs) and continuous climb operations (CCOs) and preferential runway usage (Netjasov, 2012; Graham, 2018); practices which address waste management, such as bulk buying products and/or materials, going paperless in administrative areas and recycling waste (Budd et al., 2015; ACRP, 2018); and practices which preserve and protect wildlife, such as using non-lethal management techniques and providing conservation areas (Devault et al., 2013; Martin et al., 2013).

Although Heathrow and Atlanta are the busiest passenger airports in the UK and US respectively in terms of traveller numbers, small airports (handling under 5 million passengers per annum) are the most numerous and account for the majority of the world's airports (ANNA.AERO, 2019; FAA, 2019). Within the European Common Aviation Area $^{1}$ (ECAA), over $80 \%$ of airports, equivalent to over 400 separate facilities, fall into this category ${ }^{2}$ (ANNA.AERO, 2019). Collectively, these sites handle almost four times as many passengers a year as the 80 million processed at Heathrow. Indeed, in many European countries, air transport activity at small airports caters to a significant proportion of national demand. Small airports account for approximately $40 \%$ of annual air transport movements in the UK and remote/regional airports fulfil important economic functions in other European countries including France, Norway and Greece (CAA, 2017b; ANNA.AERO, 2019). These small airports often provide lifeline connectivity services or are a major employer and economic driver in the region. Consequently, the social and economic benefits they bring are often considered to outweigh their environmental costs (Chassé and Boiral, 2016).

Despite the prevalence of small airports their adoption of EPs is limited. For example, small airport participation in the Airport Carbon Accreditation (ACA) Scheme, an industry initiative to promote 'greener' aviation, is low. The ACA Scheme, launched in 2009, 'is the only institutionally-endorsed,

\footnotetext{
${ }^{1}$ The ECAA encompasses Albania, Bosnia and Herzegovina, North Macedonia, Montenegro, Serbia, Kosovo, the $\mathrm{EU}$, Norway and Iceland; the area is subject to a unilateral agreement forming a single aviation market and the uniform enforcement of regulations across all participating countries (European Commission, 2019).

${ }^{2} \mathrm{ACl}$ Europe airport size classifications: Group 1 - Over 25 million passengers a year; Group 2 - Between 10 million and 25 million passengers a year; Group 3 - Between 5 million and 10 million passengers a year; Group 4 - Less than 5 million passengers a year (ACI-Europe, 2018).
} 
carbon management certification standard for airports' (ACl-Europe, 2009a). While over $70 \%$ of larger airports in the ECAA participate in the scheme $(25 \%$ of which operate at the highest level of accreditation - 'neutrality'), only $13 \%$ of smaller airports participate in the programme. Such statistics corroborate the findings of industry and academic studies which have reported that 'specific measures for sustainability are almost non-existent in small airports' and that 'small airports rated their [environmental] performance lowest of all [studied airports]' (ACRP, 2016, p. 41; Boiral et al., 2017, p. 7). As such, the potential for further environmental mitigation at small airports exists. According to Borial et al $(2017$, p.11) due to 'their isolation [and] frequent lack of institutional pressures... [small airports] may address sustainability issues in a different manner than other organizations'. This poses a series of important questions relating to the range of EPs that are employed at small airports, the factors which affect EP adoption, and the extent of their adoption. The aim of this research is to identify the range of EPs that are currently employed at small airports in the ECAA, observe which environmental impact categories are prioritised, and better understand the motivations and barriers to EP adoption in order to propose recommendations for future policy and practice.

The rest of this paper is structured as follows: The next section critically reviews the literature concerning airports' environmental impacts, details how EPs can be adopted in small organisations (including airports) and proposes the Technological, Organisational and Environmental (TOE) framework as a suitable theoretical underpinning for the research. The methods used for the empirical data collection and subsequent analysis are then described in section 3 before the results are presented and their significance discussed. The paper concludes with recommendations for future policy and practice. 


\section{Literature review}

The negative environmental impacts of airport operations result from both landside (before security) and airside (after security) activity. Environmental externalities encompass a wide range of impacts (see Ashford et al., (2013); Graham, (2013b); Roberts-Hughes, (2014); Budd et al., (2015); Koç and Durmaz, (2015); Sameh and Scavuzzi, (2016); Boiral et al., (2017)) which can be classified into eight broad categories:

1. Water use and quality degradation

2. Air quality and air pollution emissions

3. Energy consumption

4. Noise pollution
5

6

7

8
5. Biodiversity impacts

6. Waste production

7. Land use

8. Construction and building

9 To address and mitigate these impacts, which vary in terms of their severity and scale, airports can employ a range of environmental practices (EPs). The scope of EPs are broad and may address impacts which the airports are directly responsible for creating or those where they can influence third-party sources (e.g. aircraft engine emissions). However, extant research has shown that small airports struggle to engage with EPs (ACRP, 2008). A 2016 study, for example, discovered that almost $40 \%$ of small US airports did not employ any EPs (ACRP, 2016). Of the airports which did, $51 \%$ focused on addressing energy use using practices such as installing efficient lighting and utilising photovoltaic solar fields, $26 \%$ sought to reduce water consumption/improve water quality by taking actions such as modifying irrigation systems and installing low-flow toilets, 5\% employed noise reduction practices, which mainly focused on measuring and monitoring noise, and $2 \%$ addressed air quality and emissions by utilising electric utility vehicles and retrofitting terminal heating, ventilation and air conditioning (HVAC) systems (ACRP, 2016). Possible reasons for the low adoption of EPs at small airports relate to cost, a lack of resources and possible unwillingness on behalf of the operator to engage with tenant companies on site. For example, EPs which involve modifying a third party's 
operations (for example, airlines or concessionaires) are often avoided by smaller airports for fear of alienating customers and losing revenue (Ratliff et al., 2009; Boiral et al., 2017). Furthermore, despite the availability of 'guidebook-type' resources for small airports in the US (ACRP, 2008, 2010, $2011,2012,2015)$ best practice guidance for small airports in other world regions is limited. This is potentially problematic as the US is atypical in that the majority of its small airports remain in full public ownership (Ryerson, 2016). In many other global markets, airports are increasingly privatelyowned or are operated under a mixed public-private ownership structure ${ }^{3}$. This has the potential to affect their environmental behaviours and priorities.

Although research which directly relates to small airport engagement with EPs is scarce, an extensive body of research into small organisations' engagement, across a wide range of industries, with EPs, does exist. As small airports share many of the characteristics of small organisations (they employ low numbers of staff, have limited financial resources relative to larger firms in the same industry and are many in number (Berisha and Pula, 2015)), they are considered to be small organisations for the purpose of this research.

Organisational adoption of EPs often takes a structured approach which seeks to incorporate environmental considerations at the design and construction phase of a project. They also typically implement environmental management systems (such as ISO 14001), create environmental plans, conduct environmental reporting and integrate formal environmental management or Master Plans into the business (Monsalud et al., 2014). Certainly, development of Master Plans is now relatively commonplace within the airports sector (ACRP, 2016). However, in smaller organisations (particularly where the publication of a Master Plan is not mandated), it tends to be conducted in a more ad-hoc and less formalised way than at larger companies (Chan, 2011; ACRP, 2015; D'Souza and Taghian, 2018). According to ACRP (2016), the implementation of sustainable initiatives at

\footnotetext{
${ }^{3}$ In which the airport is operated by an independently acting enterprise whose shares are held both by private investors and public authorities (see ACl-Europe, 2016, p. 2 for further definitions.)
} 
airports requires the development of dedicated strategies, the identification of champions, the development of dedicated committees and teams, and consistent target setting and monitoring (ACRP, 2016). Such processes can be challenging and costly for small airports.

The Technological, Organisational and Environmental (TOE) Framework, proposed by Tornatzky and Fleisher (1990), has been used to explore EP adoption within small organisations. The TOE framework posits that there are conceptualised factors which can encourage and/or prevent the organisational adoption of practices and innovations (Tornatzky and Fleischer, 1990). These include: (1) technological factors, (2) organisational factors and (3) environmental factors (Lippert and Govindarajulu, 2006; Angeles, 2013; Baker, 2011; Angeles, 2014). The framework is generic and flexible, and variables can be added or removed according to context (Baker, 2011). Such flexibility enables the TOE framework to be used to examine the factors which affect EP adoption at small European airports.

As well as enabling researchers to appreciate the factors which promote the adoption of EPs, the TOE framework also permits the identification of barriers to implementation. These barriers may include (but are not limited to): a lack of funding, a lack of human resources, a lack of awareness of financial support mechanisms such as grants, competing commercial priorities, and a lack of awareness of the potential commercial benefits of adoption (ACRP, 2008, 2016; Devault et al., 2009; Boiral et al., 2017; Jaiyeola, 2017). While limited funding is often cited as the primary barrier to EP engagement, it is often a 'lack of human resources' which actually pose the greatest barrier to adoption (Hillary, 2004, p. 568). Human resources can be limited by incumbent staff members' knowledge base and skill sets (ACRP, 2008, 2016; Boiral et al., 2017). Smaller organisations often do not have access to specialist training facilities and/or cannot afford to hire dedicated staff who have the necessary knowledge and skills to adopt EPs (Simpson et al., 2004; Gupta and Barua, 2018). Staff with less specialised training will also be less able to adopt and employ complex technologies and practices, which presents a further barrier to adoption (Lin and Ho, 2008, 2011; Weng and Lin, 2011; 
Hwang et al., 2016; Kousar et al., 2017). At smaller organisations, staff may also have many roles and so balancing duties and responsibilities can be challenging and environmental concerns may not be a priority (Chassé and Boiral, 2016).

A limited understanding and awareness on the part of an organisation's senior management team can also hinder EP adoption (ACRP, 2008, 2016; Boiral et al., 2017). If this limited awareness results in senior managers not supporting EP it is unlikely EPs will be adopted (Ramakrishnan et al., 2015; Gupta and Barua, 2018). Equally, if senior managers believe 'that making the airport's operations more sustainable is the right thing to do' this can drive EP adoption (ACRP, 2015, p. 14).

Technological resources can also affect the adoption of EPs. The (in)compatibility of EPs with existing airport operations and technologies can present another obstacle to implementation. If EPs are not perceived to be easy to integrate with existing operations, EP adoption will be less likely (Weng and Lin, 2011; Hwang et al., 2016).

Although barriers to EP adoption exist, there are factors which have been shown to encourage engagement. However, there is significant debate regarding the consistency of these drivers in all operational contexts. For example, many airports' EP adoption is driven by strategic intent (Lee, 2009; Brammer et al., 2012; Agan et al., 2013). Some EPs can be advantageous for organisations as they may deliver cost reductions, improve environmental performance, enhance corporate reputation and ensure regulatory compliance (ACRP, 2015, 2016). However, small organisations do not (or cannot) always benefit from the rewards from EP adoption as the implementation costs can outweigh any financial or competitive benefits they deliver (Hillary, 2004; Simpson et al., 2004; Revell and Blackburn, 2007). However, cost reduction, improved environmental performance, enhanced stakeholder relations and legislative compliance are often anticipated outcomes of EP adoption (ACRP, 2015, 2016). survey reported that airports who had not employed EPs stated that they would be more likely to do 
so if communities surrounding airports and passengers expressed concerns about the environment and demanded change (ACRP, 2016). It has been suggested that smaller organisations are often responsive to social pressure, however, in some cases (particularly where organisations are in more rural locations) these pressures are not necessarily present and so do not act as drivers for change (Darnall et al., 2010).

Where drivers for the voluntary adoption of EPs are ineffective, legislation and regulation can act as a powerful incentive to adoption (ACRP, 2016). However, a study of small Canadian airports noted that despite the introduction of new regulations governing surface runoff, staff did not have the time or resources to receive the training that was necessary for compliance (Boiral et al., 2017). Many small firms are also not 'eco-literate' and often lack the resources and knowledge to appreciate how legislation affects them (Hörisch et al., 2015). In addition, legislation is often inapplicable to smaller organisations and compliance is not monitored or policed (Brammer et al., 2012; Agan et al., 2013). For example, the EU Environmental Noise Directive (which concerns the assessment and management of airport noise) does not apply to airports with fewer than 50,000 annual aircraft movements (European Union, 2002).

Regulation of small airports is problematic as 'frequently these airports are subject to multiple levels of policy compliance with respect to their aviation operations... environmental impacts, and relationship to other airports' (Donehue and Baker, 2012, p. 235). Certainly, relatively little is known about the types and range of employed EPs at small airports, particularly outside of the US. There is a need for both academics and policy makers to understand the status of small airport engagement with EPs and appreciate how to encourage adoption in order to mitigate the environmental impact these airports generate. 
119 An online self-completion questionnaire was developed and distributed via email to all commercial

120 airports within the ECAA which handled under 5 million passengers in 2017 (and hence defined as

121 'small'). Data was obtained from national reporting bodies (most commonly national aviation

122 authorities) or, where this was unavailable, from official passenger statistics of individual airports.

123 This provided a total population of 441 airports. Airports were excluded from the study if they did

124 not have an accessible website and/or a contact email. As a result, 28 airports were excluded,

125 leaving a population of 413. Figure 1 displays the ECAA, divided into geographical regions of north,

126 south, east and west (as defined by the UN.) and the location of the 413 small airports. 


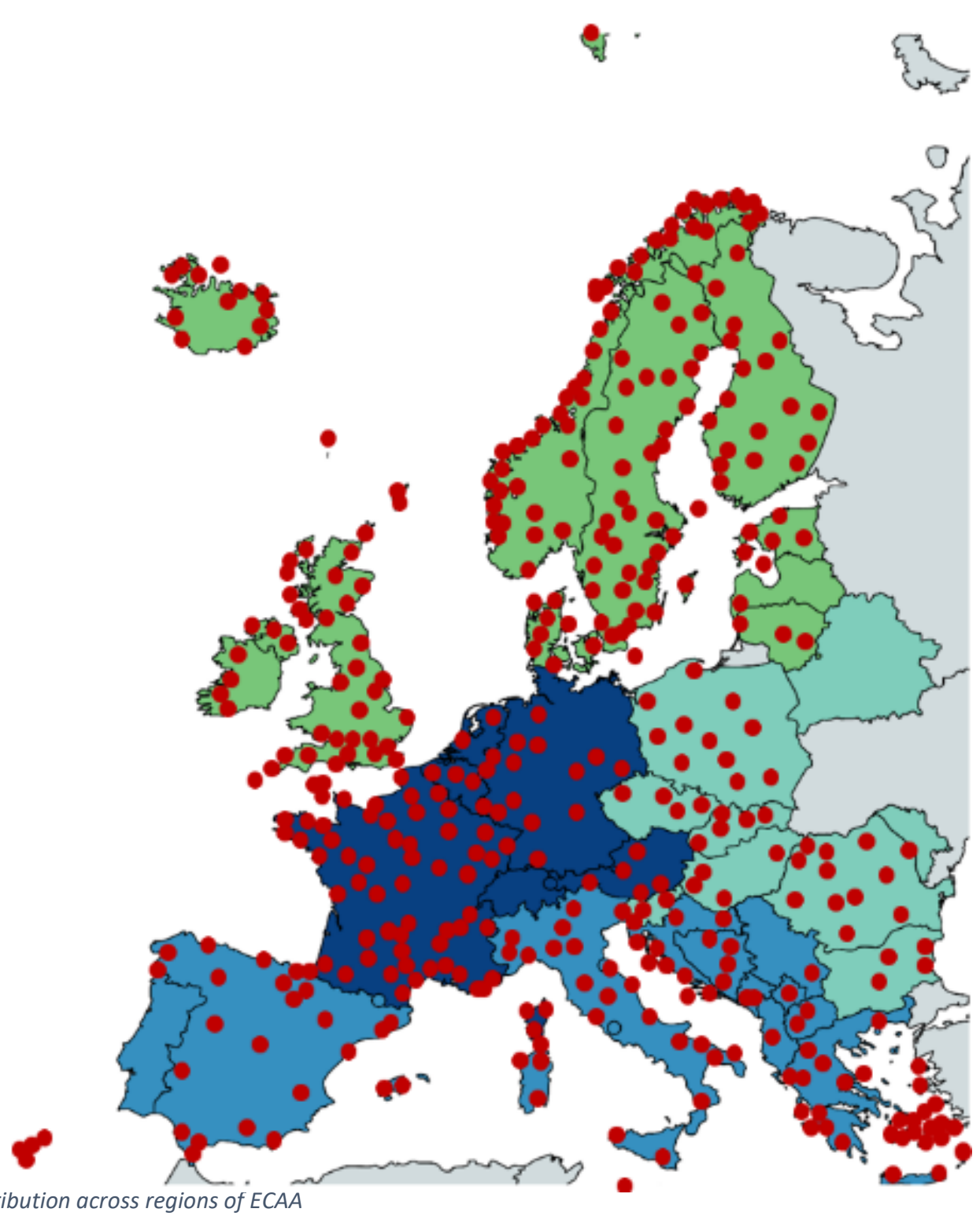

Figure 1 Small airport distribution across regions of ECAA Source: (United Nations, 2020)

The ECAA offers an interesting and varied region of study as it is one of the largest aviation markets

in the world, comprises multiple sovereign states and supports a mature aviation market which has

been progressively liberalised since the mid-1990s. The focus on a mature market was deliberate as

'in general, emerging markets lag behind developed economies in environmental stewardship'

(Jayanti and Rajeev Gowda, 2014, p. 130).

The online survey was conducted in English as English is the international language of commercial aviation and international airport operations. Participants were assured anonymity in exchange for their participation to encourage truthful and honest responses. Ethical approval was received from the lead researcher's institution. A list of the managers and/or environmental officers' email 
addresses for each airport was compiled from each individual airport's website. A link to the survey was emailed on March $29^{\text {th }}$ 2019. Follow up emails were sent to those who had not completed the survey on April $15^{\text {th }}$ and $22^{\text {nd }}$ to encourage additional responses. The survey was live for 6 weeks and this enabled the whole population to be approached (Wright, 2005). An email survey was chosen to promote a high response rate as previous research into small organisations reported low response rates on account of the limited time of staff members to complete survey requests (Macpherson and Wilson, 2003; Gadenne et al., 2009).

The survey comprised four distinct sections. The first and second obtained information about the respondent and the airport (or airports) they worked for. The third section asked respondents to rate the extent of EP adoption at their airport/s and identify which EP practice types were currently employed across eight environmental target areas: (1) water use reduction/quality improvement, (2) emissions reduction, (3) energy-use reduction, (4) noise reduction, (5) biodiversity improvement/protection, (6) waste reduction, (7) land use management, (8) design of green buildings. For each target area, respondents selected a value on a 5-point Likert scale from "not at all" to "to a great extent". The sum of these responses provided an overall value of the extent of EP adoption (see Lin and Ho, 2008, 2011; Weng and Lin, 2011). To encourage respondents to consider and identify all relevant practices, indicative (but not exhaustive) examples from the literature were included in each question by way of prompts. In addition, the scope of relevant practices included those environmental impact sources that the airport operator has direct control over and those where they can influence third-party operations. For instance, respondents were asked "Does your airport: Reduce noise from airborne aircraft (e.g.: modify descent patterns, employ noise abatement procedures)?" and "Does your airport: Reduce emissions from surface access traffic (e.g.: provide incentives for low emission passenger vehicles, encourage trip reduction schemes such as subsidising public transit for passengers or providing staff ride share schemes, provide infrastructure for alternatively fuelled vehicles)?" The provision of such examples encouraged respondents not only to report the practices implemented which directly affect airport operations, but also those 
imposed by the airport which affect third parties' operations at the airport (including airlines, concessionaires, and ground access companies).

The fourth section of the survey asked respondents to indicate their level of agreement with a number of predefined statements. Responses were obtained through a 5-point Likert scale which offered a range of options from "strongly disagree" to "strongly agree". The statements were developed using Tornatzky and Fleisher's (1990) TOE Framework (see Table 1).

Table 1 Factors investigated in the survey (based on the TOE framework)

\begin{tabular}{|c|c|c|}
\hline Context & Factor & Definition \\
\hline \multirow[t]{3}{*}{ Technological } & Complexity & $\begin{array}{l}\text { The degree to which a new practice 'is seen as difficult to } \\
\text { understand and use' (Ruslan et al., 2014, p. 61). }\end{array}$ \\
\hline & Compatibility & $\begin{array}{l}\text { The degree to which a new technology matches the } \\
\text { existing needs, values and experiences of a firm (Ramdani } \\
\text { et al., 2013; Bin Ibrahim and Binti Jaafar, 2016). }\end{array}$ \\
\hline & $\begin{array}{l}\text { Relative } \\
\text { advantage }\end{array}$ & $\begin{array}{l}\text { The perception that a new practice is better than what is } \\
\text { already in place (Wang et al., 2010; Weng and Lin, 2011). }\end{array}$ \\
\hline \multirow[t]{3}{*}{ Organisational } & $\begin{array}{l}\text { Top } \\
\text { management } \\
\text { support }\end{array}$ & $\begin{array}{l}\text { The extent to which an organisation helps and encourages } \\
\text { staff members to use a new practice (Weng and Lin, 2011). }\end{array}$ \\
\hline & $\begin{array}{l}\text { Human } \\
\text { resources }\end{array}$ & $\begin{array}{l}\text { The 'learning and innovative capabilities' of staff members } \\
\text { (Lin and Ho, 2011, p. } 75 \text { ). }\end{array}$ \\
\hline & Size & Total annual passengers 2017. \\
\hline Environmental & $\begin{array}{l}\text { Consumer } \\
\text { pressure }\end{array}$ & $\begin{array}{l}\text { The force of 'normative pressures' on an organisation } \\
\text { causing behaviour modification in the search for legitimacy } \\
\text { (Hwang et al., 2016, p. 9). }\end{array}$ \\
\hline
\end{tabular}




\begin{tabular}{|c|c|}
\hline $\begin{array}{l}\text { Regulatory } \\
\text { pressure }\end{array}$ & $\begin{array}{l}\text { 'Coercive pressures, such as threats or legal sanctions' } \\
\text { exerted from national and supranational organisations } \\
\text { (Hwang et al., 2016, p. 8). }\end{array}$ \\
\hline Support & $\begin{array}{l}\text { Mechanisms such as 'financial incentives, technical } \\
\text { resources [and] human resource training' provided by } \\
\text { Government bodies and external stakeholders (Piaralal et } \\
\text { al., } 2015, \text { p. } 256 \text { ). }\end{array}$ \\
\hline
\end{tabular}

The survey was pilot tested between March 6th and March 17th, 2019, on a sample of 54 airports

171 (13\% of the total population). Results from the pilot survey indicated that some of the statements in the fourth part of the survey were not (based on Cronbach's Alpha and factor analysis) reliable indicators for the factors they intended to measure. These statements were subsequently modified to improve the construct validity of the final survey instrument. Additionally, the phrasing of certain questions and statements was modified to improve their clarity and prevent confusion among respondents for whom English was not their first language.

Factor analysis was conducted on the measurement statements to confirm the validity of the final survey instrument (Roberts and Priest, 2006). A principal components analysis with direct oblimin rotation was used as the factors were correlated. The quality of the factor analysis was assessed using the Kaiser-Meyer-Olkin (KMO) measure of sampling adequacy and Bartlett's test of sphericity; the KMO was 0.683 , above the recommended value of 0.5 . Bartlett's test was significant $\left(\chi^{2}=\right.$ 3469.680, $p$ <.001) (Williams et al., 2010). Cronbach's Alpha was used to test for internal consistency; as all alpha values are above 0.7 , the consistency was confirmed (Tavakol and Dennick, 2011). Factor scores were also obtained which were used in the subsequent regression. The results of the factor analysis are presented in Table 2. 
As the survey employed a single informant technique it was necessary to test for common method bias. Harman's single factor test was used. The results showed that a single factor accounted for only $41 \%$ of the total variance, indicating that common method bias was not an issue (Podsakoff et al., 2003). A response rate of $26.4 \%$ was achieved (Northern Europe $=40.2 \%$; Eastern Europe $=20.9 \%$; Southern Europe $=23.4 \%$; Western Europe $=3.6 \%$ ), which is comparable with other studies investigating environmental behaviours of organisations and small organisations (Gadenne et al., 2009; Sroufe, 2009; Darnall et al., 2010). Given this figure, it was necessary to check for nonresponse bias. It is assumed that non-respondents are more similar to late-respondents than they are to early-respondents (Weng and Lin, 2011). By using Armstrong and Overton's (1977) method, comparing the average responses of late (those who responded in the second three weeks) and early respondents (those who responded in the first three weeks) using an independent samples Ttest, it was found that non-response bias was not a concern, as there were no significant differences in the responses (Armstrong and Overton, 1977). 


\begin{tabular}{|c|c|c|c|}
\hline Context & Factor & Statement & Factor loading \\
\hline \multirow[t]{11}{*}{ Technological } & \multirow{4}{*}{$\begin{array}{l}\text { Complexity } \\
\alpha=.814\end{array}$} & Understanding environmental practices is difficult & .788 \\
\hline & & Learning about environmental practices is difficult & .539 \\
\hline & & $\begin{array}{l}\text { Previous experience of having adopted environmental practices makes adopting } \\
\text { environmental practices easier }\end{array}$ & .718 \\
\hline & & Sharing knowledge of environmental practices is difficult & .987 \\
\hline & \multirow[t]{4}{*}{$\begin{array}{l}\text { Compatibility } \\
\alpha=.944\end{array}$} & $\begin{array}{l}\text { Environmental practices are compatible with our existing airport practices and } \\
\text { operations }\end{array}$ & .866 \\
\hline & & Environmental practices are consistent with our airport's(') values & .944 \\
\hline & & Environmental practices are consistent with our airport's(') environmental goals & .906 \\
\hline & & Environmental practices are consistent with our airport's(') strategic goals & .918 \\
\hline & \multirow{3}{*}{$\begin{array}{l}\text { Relative advantage } \\
\alpha=.706\end{array}$} & Environmental practices can enhance our airport's(') reputation & .775 \\
\hline & & Environmental practices can improve the financial performance of our airport(s) & .759 \\
\hline & & Environmental practices can provide competitive advantages for our airport(s) & .786 \\
\hline
\end{tabular}




\begin{tabular}{|c|c|c|c|}
\hline \multirow[t]{6}{*}{ Organisational } & $\begin{array}{l}\text { Top management } \\
\text { support }\end{array}$ & $\begin{array}{l}\text { Senior management encourages staff members to learn about environmental } \\
\text { practices }\end{array}$ & .952 \\
\hline & \multirow[t]{2}{*}{$\alpha=.911$} & $\begin{array}{l}\text { Senior management provides support for staff members to learn about environmental } \\
\text { practices }\end{array}$ & .950 \\
\hline & & Senior management can help staff members dealing with environmental problems & .873 \\
\hline & \multirow{2}{*}{$\begin{array}{l}\text { Human resources } \\
\alpha=.814\end{array}$} & Staff members can share knowledge with each other easily & .961 \\
\hline & & Staff members can use new practices to solve operational issues easily & .862 \\
\hline & Size & No statements used; 2017 passenger statistics taken as objective measure & \\
\hline \multirow[t]{6}{*}{ Environmental } & \multirow{3}{*}{$\begin{array}{l}\text { Consumer pressure } \\
\alpha=.810\end{array}$} & Our passengers require us to improve environmental performance & .709 \\
\hline & & Caring for the environment is an important consideration for our passengers & .923 \\
\hline & & $\begin{array}{l}\text { Caring for the environment is an important consideration for the airlines at our } \\
\text { airport(s) }\end{array}$ & .861 \\
\hline & \multirow{3}{*}{$\begin{array}{l}\text { Regulatory pressure } \\
\alpha=.895\end{array}$} & National Government sets stringent environmental regulations & .643 \\
\hline & & $\begin{array}{l}\text { The environmental regulations set by national government affect our airport(s) } \\
\text { operations }\end{array}$ & .748 \\
\hline & & National environmental regulations do not affect our airport(s) operations & .983 \\
\hline
\end{tabular}




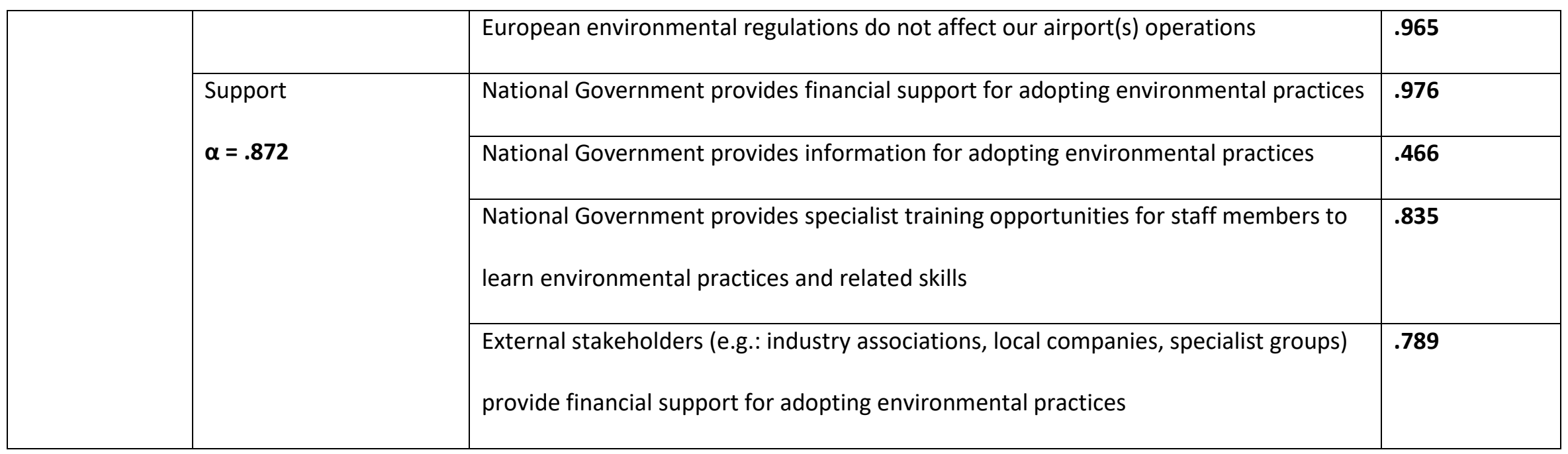


202 The survey received 109 valid responses from airports across Europe. Table 3 shows the

203 geographical location, ownership ${ }^{4}$ and number of staff members employed at the airports who

204 responded to the survey. The average number of passengers at the respondent airports was 403,465

205 in 2017.

Table 3 Airport characteristics

\begin{tabular}{|c|c|c|}
\hline Variable & Category & Percentage of sample \\
\hline \multirow[t]{4}{*}{ Location } & Northern Europe & 66.1 \\
\hline & Southern Europe & 22.9 \\
\hline & Eastern Europe & 8.3 \\
\hline & Western Europe & 2.8 \\
\hline \multirow[t]{3}{*}{ Ownership } & Public & 26.6 \\
\hline & Private & 11.0 \\
\hline & Mixed & 62.4 \\
\hline \multirow[t]{7}{*}{ Number of staff members } & $<10$ & 1.8 \\
\hline & $10-49$ & 24.8 \\
\hline & $50-99$ & 35.8 \\
\hline & $100-149$ & 20.2 \\
\hline & $150-199$ & 2.8 \\
\hline & $200-249$ & 11.9 \\
\hline & $250+$ & 2.8 \\
\hline
\end{tabular}

${ }^{4}$ Ownership is defined in accordance with the definitions used in $\mathrm{ACl}-\mathrm{E}$ 's airport ownership report (see $\mathrm{ACl}$ Europe, 2016, p. 2) 
209 Within the study, respondents were asked to identify which practice types, if any, their airport had

210 adopted. Figure 2 shows the percentage of airports addressing ${ }^{5}$ each of the 8 target areas, by

211 geographic region and the overall percentage. The figure also shows the mean ${ }^{6}$ number of practice

212 types employed to address each target.

213

\footnotetext{
${ }^{5}$ Meaning that an airport had at least one EP employed addressing the target area.

${ }^{6}$ For each target area at least two example practices were offered for selection in the survey and an additional option of 'other' was provided so that any unlisted practices could be added by the respondent, so as to not limit the range of possible practices.
} 


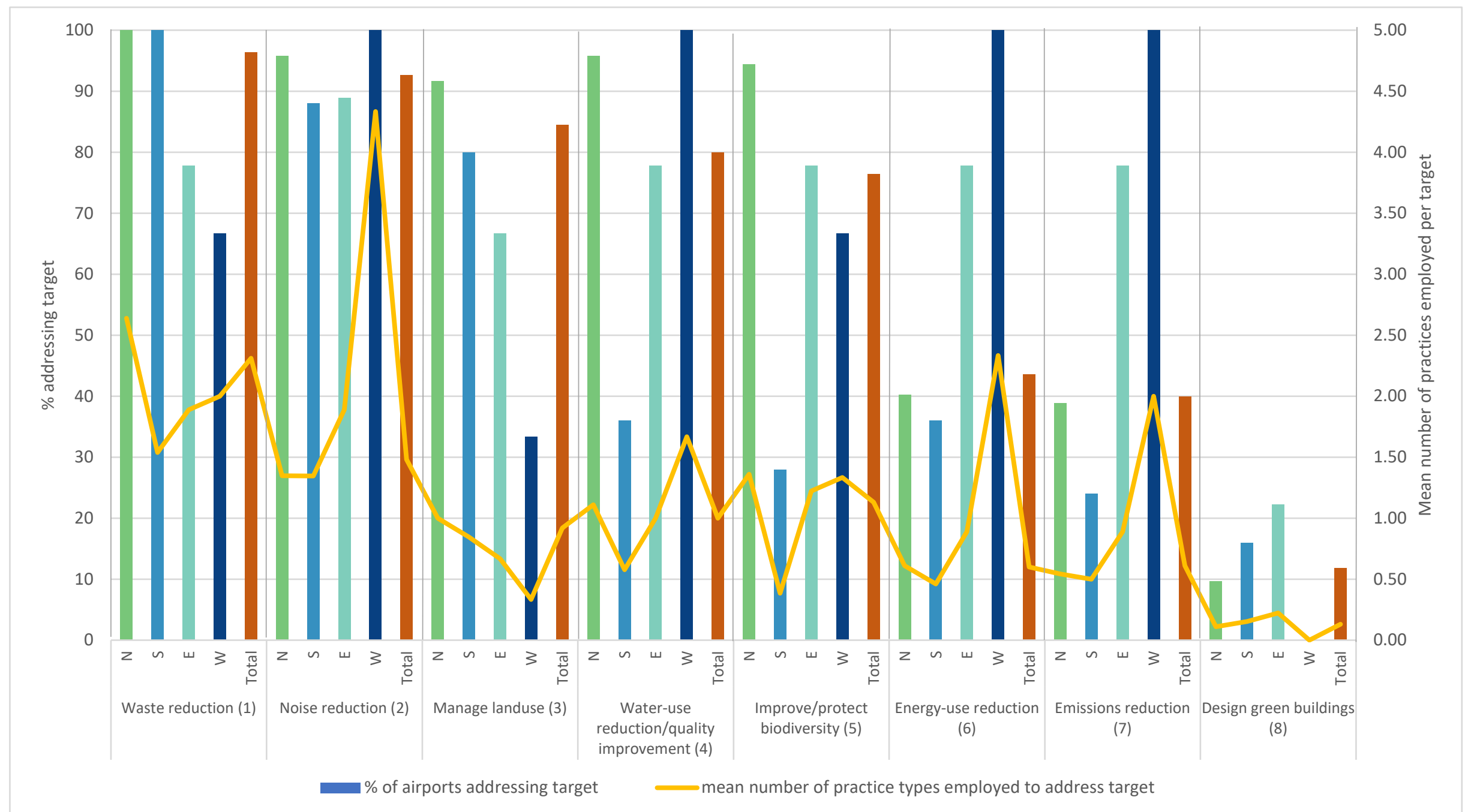

Figure 2 Environmental target areas addressed 
The most commonly addressed target areas were waste and noise reduction, and the least common were emissions reductions and the design of green buildings.

Airports in Western Europe employed, on average, a greater number of practice types to address noise reduction. For waste reduction, the target is addressed by a higher percentage of airports in Northern and Southern Europe. Airports in Northern Europe also employed, on average, a greater number of practice types to address waste reduction. In Eastern Europe, a higher percentage of airports have employed green buildings than other regions. Airports in North and West Europe tend to address more environmental target areas with more EPs. There is a potential that being close geographical neighbours they have a shared environmental culture influencing their behaviour.

It is possible that different population densities around the individual airports result in noise reduction being a greater focus for Western Europe (where the population densities in Germany and the Netherlands the 236.7 and 508.5 people $/ \mathrm{km}^{2}$ respectively) than in Northern Europe (where the population densities in Norway and Sweden are 14.5 and 24.7 people $/ \mathrm{km}^{2}$ respectively) (World Bank, 2017). This would suggest that fewer people are impacted by noise in Northern Europe than other regions.

Green buildings were not a common target in any region which is likely a result of the high cost associated with their design, building and certification. One respondent highlighted that buildings at their airport had been built to formal certification standards, however certification had not been pursued as the administrative costs were too high. In Eastern Europe, the majority of airports indicated that where green buildings had been constructed, they were done so in accordance with national guidelines, as opposed to formal certification standards. This suggests that while there is interest in designing green buildings in this region, formal recognition is not important. 


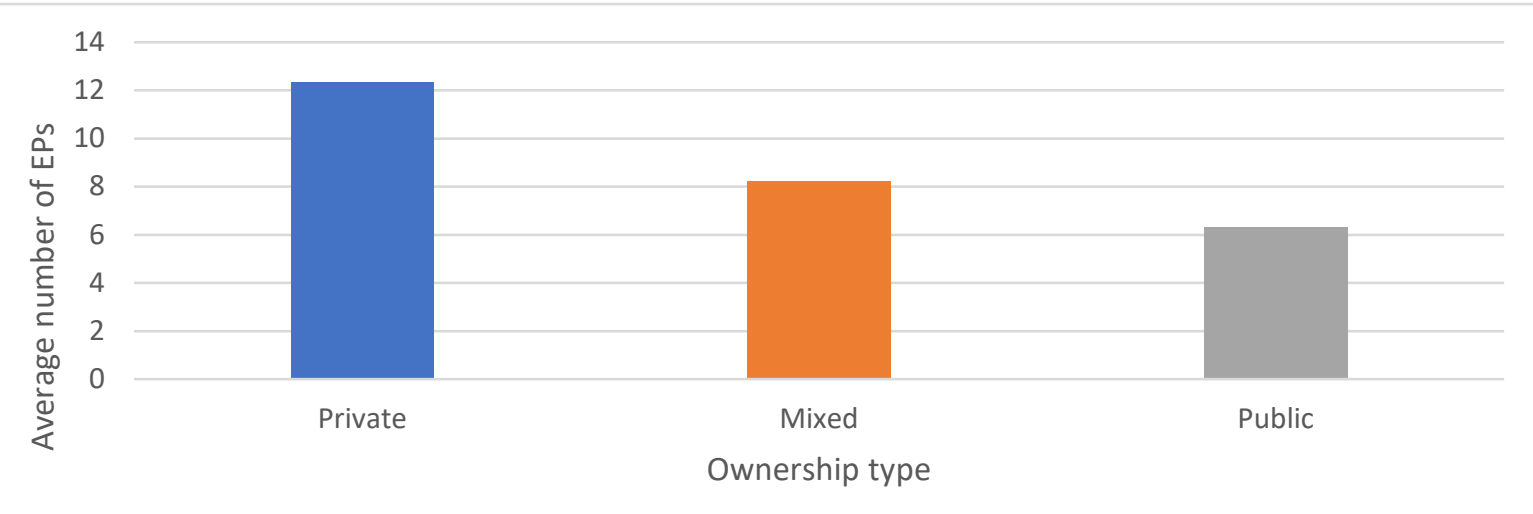

Figure 3 Average number of EPs implemented by airport ownership type

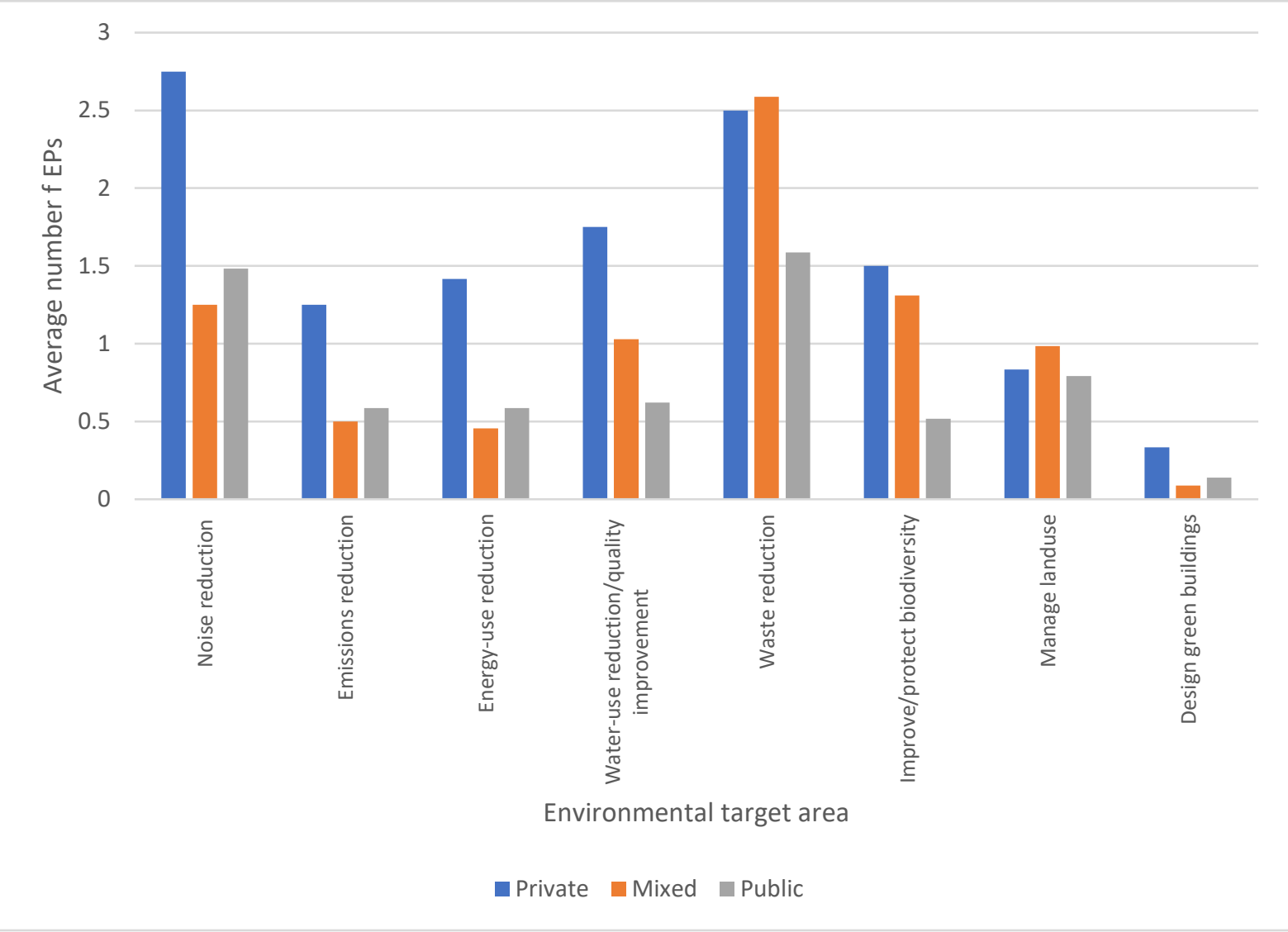

Figure 4 Average number of EPs implemented by environmental target area and airport ownership type

Figures 3 and 4 show EP employment by airport ownership type. The results show that, on average, privately owned airports employ more EPs in total and across all environmental target areas, with

240 the exception of waste reduction and land use management. This suggests that commercial

241 involvement has a positive impact on EP adoption as EP adoption could impart potentially important reputational benefits as being a responsible company and thus attracting/retaining custom. This supports Lee (2009), Brammer et al (2012) and Agan et al. (2013) who suggest that there are 
245 as they tend to be the smallest airports which are focused on regional connectivity, therefore

246 environmental concerns may be a lesser concern for them owing to their size and primary strategic

247 goals. However, again, further research is needed to confirm this.

\subsection{Practice types}

249 Following the examination of the target areas, further analysis explored the practice types which are employed to address these target areas. Figure 5 displays the \% of airports employing each practice type $^{7}$ and whether the practice involves the airport modifying third party operators' operations

252 (demarked by an asterisk.)

\footnotetext{
${ }^{7}$ Building Research Establishment Environmental Assessment Method (BREEAM) and Leadership in Energy and Efficiency Design (LEED) are examples of green building certification programs, meaning that buildings have been built to certain environmental standards and meet specified criteria set by certification boards.
} 
Reduce/reuse/recycle waste from administrative areas

Manage water polluting processes

Avoid operating on and/or remediate contaminated land

Reduce/reuse/recycle waste from terminal areas

Have conservation programs within the airport boundary

Collect organics for composting

Conduct noise mapping

Employ energy efficiency initiatives

Use non-lethal techniques

Track and monitor noise complaints

Participate in local land-use planning

Restrict/prohibit certain aircraft types*

Utilise alternative energy sources

Employ initiatives to reduce water use

Participate in formal emissions management programs

Reduce noise from airborne aircraft*

Reduce/reuse/recycle waste from aircraft*

Reduce emissions from airport ground vehicles

Partner with NGOs/wildlife organisations

Reduce noise from aircraft on the ground*

Reduce emissions from surface access*

Reduce emissions from aircraft on the ground*

Have green buildings built in accordance with national guidelines

Have a community outreach program

Collect and reuse rainwater

Reduce emissions from aircraft in the air*

Gain value from waste

Have conservation programs outside of the airport boundary

Have a sound insulation program

BREEAM certified buildings

Collect and reuse greywater

LEED certified buildings

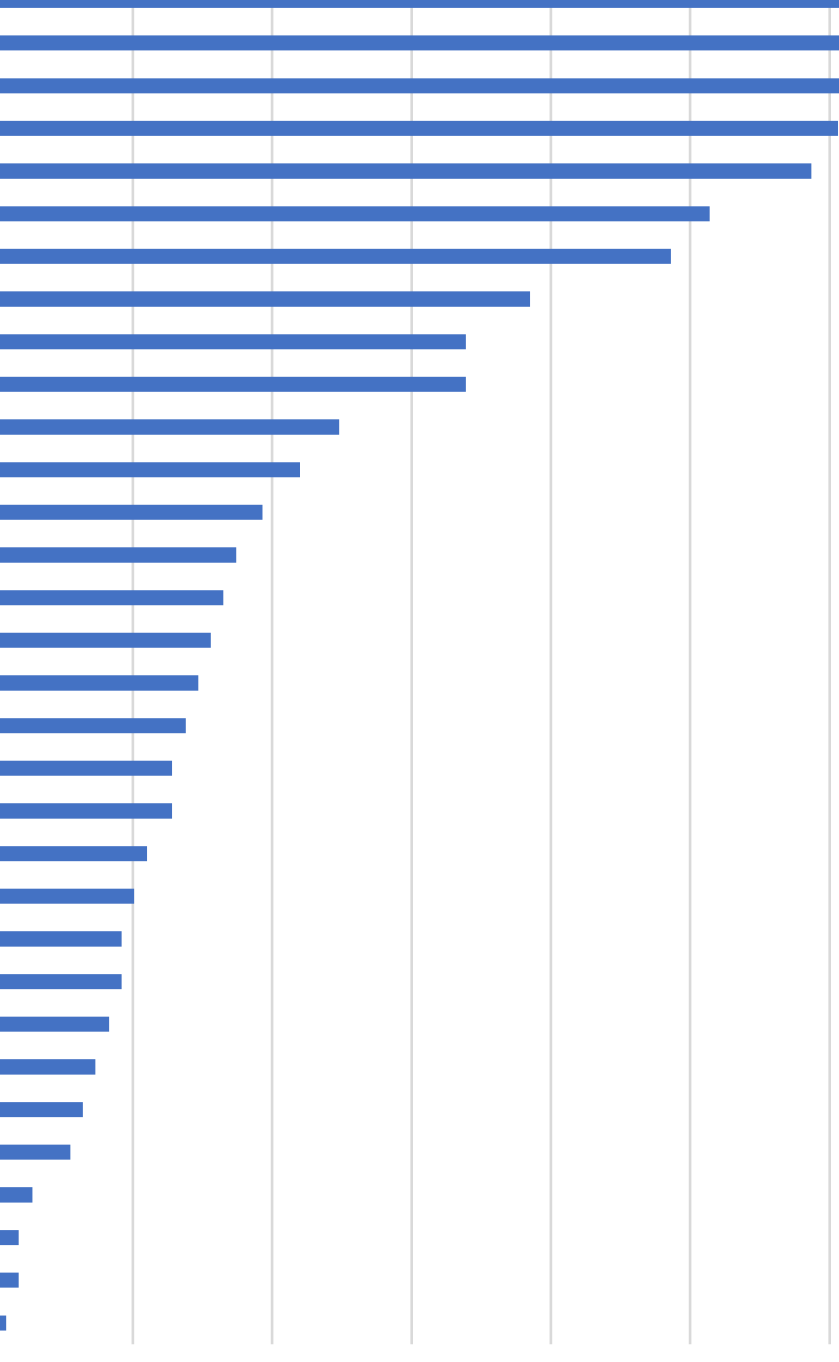

Figure 5 Frequency of practices types employed (\%) 
On average, airports employed eight practice types across five target areas. All respondent airports employed at least one practice type; no respondents employed all practice types, indicating that there is scope for improvement with regards to EP engagement.

257

Only six practice types were employed by over $50 \%$ of respondents. In comparison, ten practice types were employed by fewer than $10 \%$. Of the six most commonly employed practice types, three were aimed at reducing waste. Almost all airports reported addressing waste; the majority of which did so by recycling waste from administrative areas and passenger terminals. A large proportion of airports also indicated that they composted organic materials; this corroborates findings from the 2018 ACRP study which indicated that composting was a practice growing in popularity at airports (ACRP, 2018). It is not evident from this study's results, however, for what purpose the resulting compost is used. Future research may usefully explore this. Recycling waste from aircraft was identified as a further, however less common, practice aimed at reducing waste. Existing literature focusing on waste management at larger airports highlights that recycling waste from aircraft is not common practice as international health and safety legislation aimed at maintaining a nation's sanitary border require international catering waste to be sent to deep landfill or incinerated (Pitt et al., 2002). The survey results here showed that almost $15 \%$ of the airports reported recycling waste from aircraft; this is likely because many of these smaller airports receive domestic flights only and so international health and sanitary regulations do not apply.

The remaining three most common practice types were aimed at improving water quality by managing surface run-off pollution, managing land use by avoiding operating on/remediating contaminated land and protecting/improving biodiversity by having conservation areas within the airport boundary. Having conservation programmes within the boundary has the potential to increase wildlife hazards which makes them uncommon at larger airports (Martin et al., 2013). However, it is likely that at these smaller airports the risk of wildlife strike is lower and so conservation programmes can be safely pursued. 
Practices targeting noise reduction do not feature among the most common practice types. It is frequently stated in literature that noise is the greatest environmental concern for airports (Wolfe et al., 2014; Grampella et al., 2017; Rodríguez-Díaz et al., 2017), however, while noise reduction is a commonly targeted area for airports, very few small airports (just over 25\%) indicated that they employed more than one practice type to address the issue. Where noise reducing practices were employed, almost $25 \%$ of airports in this study indicated that they employed practices to reduce noise emissions which restricted or modified airlines' operations. Extant research into the environmental practices of small airports indicated that such facilities were reluctant to impose operational restrictions on airlines for fear of losing custom (Dimitriou and Voskaki, 2010; Boiral et al., 2017).

Of the least common practice types (employed by fewer than $10 \%$ of respondents) the majority feature practices and technologies which are complex and/or expensive; for example collecting and reusing water (see Ashford et al., 2013; Couto et al., 2015). It would be important to consider that the airports using these practice types may be situated in more remote areas in which connections to mains water supplies are limited and reuse of water may be a necessity. Also uncommon is the design of green buildings. Where small airports report designing green buildings, they are often built in accordance with national standards, and not to certified levels of international bodies such as LEED and BREEAM. The limited engagement was attributed to cost by some respondents. Practices which involve modifying third party operations are also not commonly implemented. While some scholars have suggested that airports have a limited jurisdiction over pollutants, others contend that airports can exert some influence over third party operators' actions (Hansen et al., 2013, p. 166; Ryerson, 2016). A limited number of respondent airports indicated that they imposed practices on airlines to address noise pollution, however, such interventions were not widespread and, as such, our findings corroborate those of Boiral et al. (2017). 
Practices targeting emissions reductions (either local air pollution or greenhouse gases) were not commonly employed. After noise, atmospheric emissions have been identified as a significant environmental concern for airports (Daley, 2010; Wolfe et al., 2014; Rodríguez-Díaz et al., 2017; addressing this target area. One respondent stated that their airport conducted regular air quality monitoring and that the results indicated that no mitigating action was required. Thus, it may be the case that for many smaller airports there are limited air quality and emission issues and so minimal action is taken. However, the act of monitoring would suggest that concern and awareness exist.

On average, each practice type was employed more commonly by the 'larger small airports' (those with more than 1 million passengers a year,) with the exception of some practices addressing waste reduction, biodiversity management and green buildings. Airports handling under 1 million passengers a year recycled waste from both terminal areas and aircraft, composted organics, employed conservation programmes both inside and outside of the airport site, used non-lethal wildlife control methods and constructed buildings to LEED, BREEAM and national standards more commonly than the larger airports in the sample. It is possible that recycling waste from buildings may be easier for smaller airports as there is less to manage than at larger airports; also, as discussed previously, the smaller airports tend to handle primarily domestic traffic, meaning that international food waste laws do not apply and they are able to recycle more waste from aircraft. It may also be the case that the smaller airports in the sample handle fewer aircraft annually than their larger counterparts, and so are able to employ conservation programmes as the exposure risk for aircraft strikes with wildlife is less than at airports with more annual movements. It is unclear from the results why green buildings are more commonly constructed by the smaller airports in the sample, as the cost of such projects has specifically been highlighted as a barrier to their construction. There is potential that smaller scale construction at smaller sites has a lesser cost attached and that the cost savings that green buildings can bring (e.g. from reduced heating 
requirements) are appealing and cost effective at smaller sites. Further research would be required to confirm this.

\subsection{Classification of airports by EP engagement}

331

The survey enabled airports to be clustered into three groups according to the number of environmental impact target areas they addressed and how many environmental practice types they employed.

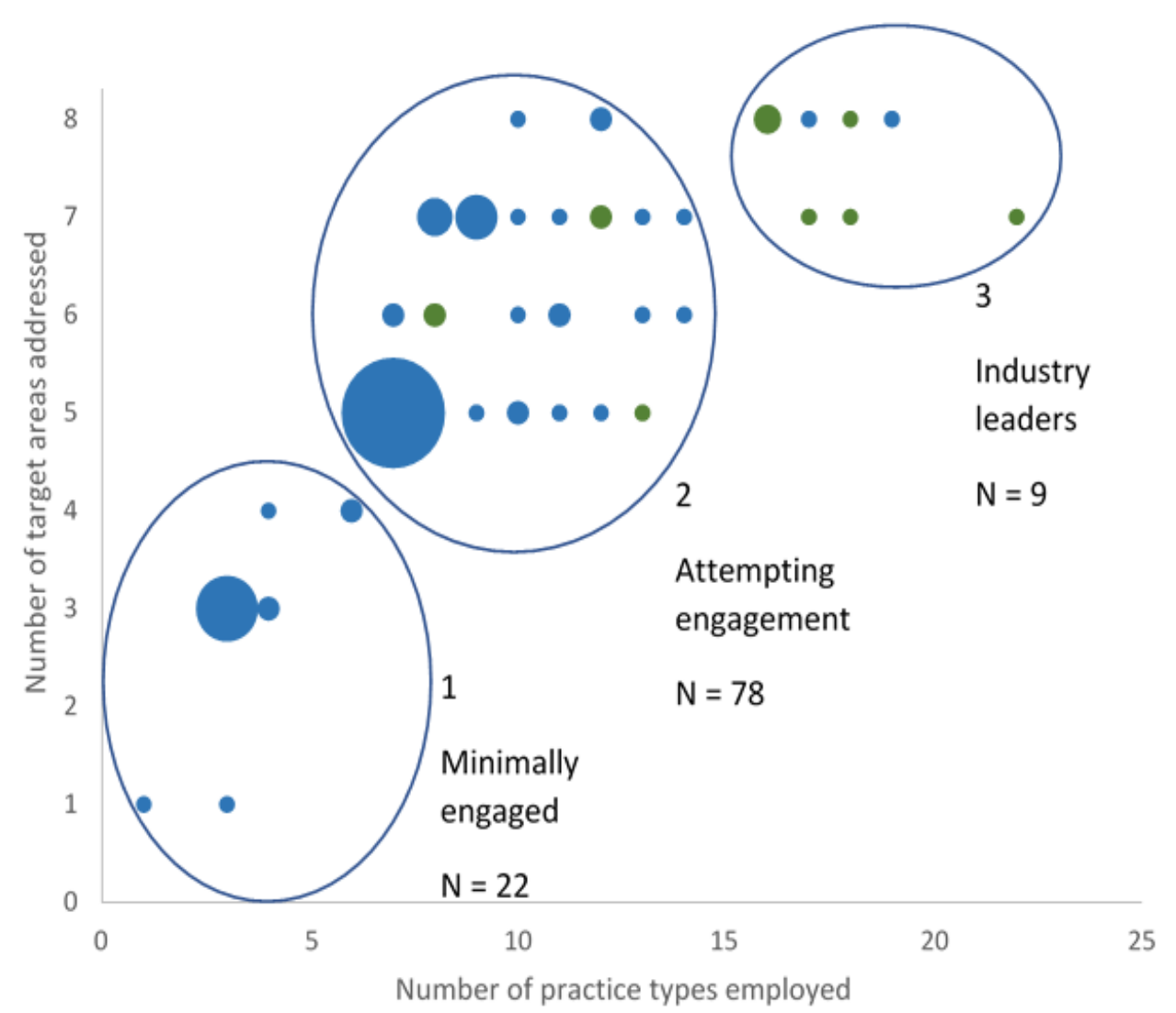

Size of airport

01 million PPA

$>1$ million PPA

Figure 6 Classification of airports by EP engagement levels Plot size representative of how many airports represented by plot point.

Figure 6 shows that the majority of airports fall within Group 2, i.e. they are 'attempting engagement' by employing a mid-range number of practice types which address a medium-to-high number of target areas. These airports appear to be attempting engagement with EPs but are not engaging at the same level as the 9 'industry leaders' in Group 3. Airports in Group 3 employ of a broad range of practice types that address a high number of target areas. This contrasts with Group 
3411 airports who we define as 'minimally engaged' as they employ few practice types and address few of the target areas.

Airports within each group were then segmented by size (Table 4). Results showed that, on average, the 'larger' small airports (handling 1-5 million p.p.a) employed significantly more practice types and addressed more targets than the 'smaller' small airports (which handled under 1 million p.p.a). This suggests that subgroupings by size exist within this population which impact an airport's ability or need to engage with EPs.

Table 4 Mean number of practice types and targets addressed by airport size

\begin{tabular}{|c|c|c|c|c|c|c|c|c|}
\hline \multirow[t]{2}{*}{ Size group } & \multicolumn{4}{|c|}{ Practice types employed } & \multicolumn{4}{|c|}{ Target areas addressed } \\
\hline & Mean & $\mathrm{t}$ & $d f$ & $\mathrm{p}$ & Mean & $\mathrm{t}$ & $d f$ & $\mathrm{p}$ \\
\hline $\begin{array}{l}<1 \text { million PPA } \\
\text { (smaller) }\end{array}$ & 7.50 & -3.526 & 15.961 & 0.03 & 5.13 & -3.018 & 107 & 0.03 \\
\hline $\begin{array}{l}>1 \text { million PPA } \\
\text { (larger) }\end{array}$ & 12.33 & & & & 6.40 & & & \\
\hline
\end{tabular}

The identification of size subgroups led to an additional difference being noted between the engagement groups identified in Figure 6. Airports with more than 1 million p.p.a are found more commonly in EP engagement group 3 (and somewhat in group 2), whereas all cases in EP engagement group 1 are airports handling under 1 million p.p.a. This suggests that the size of the airport impacts either the capability or need to engage with EPs. However, there are a large number of airports with less than 1 million p.p.a in group 2 and some more anomalous cases found in group 3. This would suggest that the size of the airport is not the only factor affecting EP engagement. Based on the TOE framework (Tornatzky and Fleischer, 1990), further analysis was therefore conducted to explore the relationships between the technological, organisational and environmental factors and EP adoption. 
361 The following subsections discuss the contextual factors affecting EP adoption at small European

362 airports.

363

364

365

366

367

368

369

370

371

372

373

374

375

376

377

\subsubsection{Technological context}

Figure 7 presents the mean responses ${ }^{8}$ to individual statements in the survey relating to the technological context.

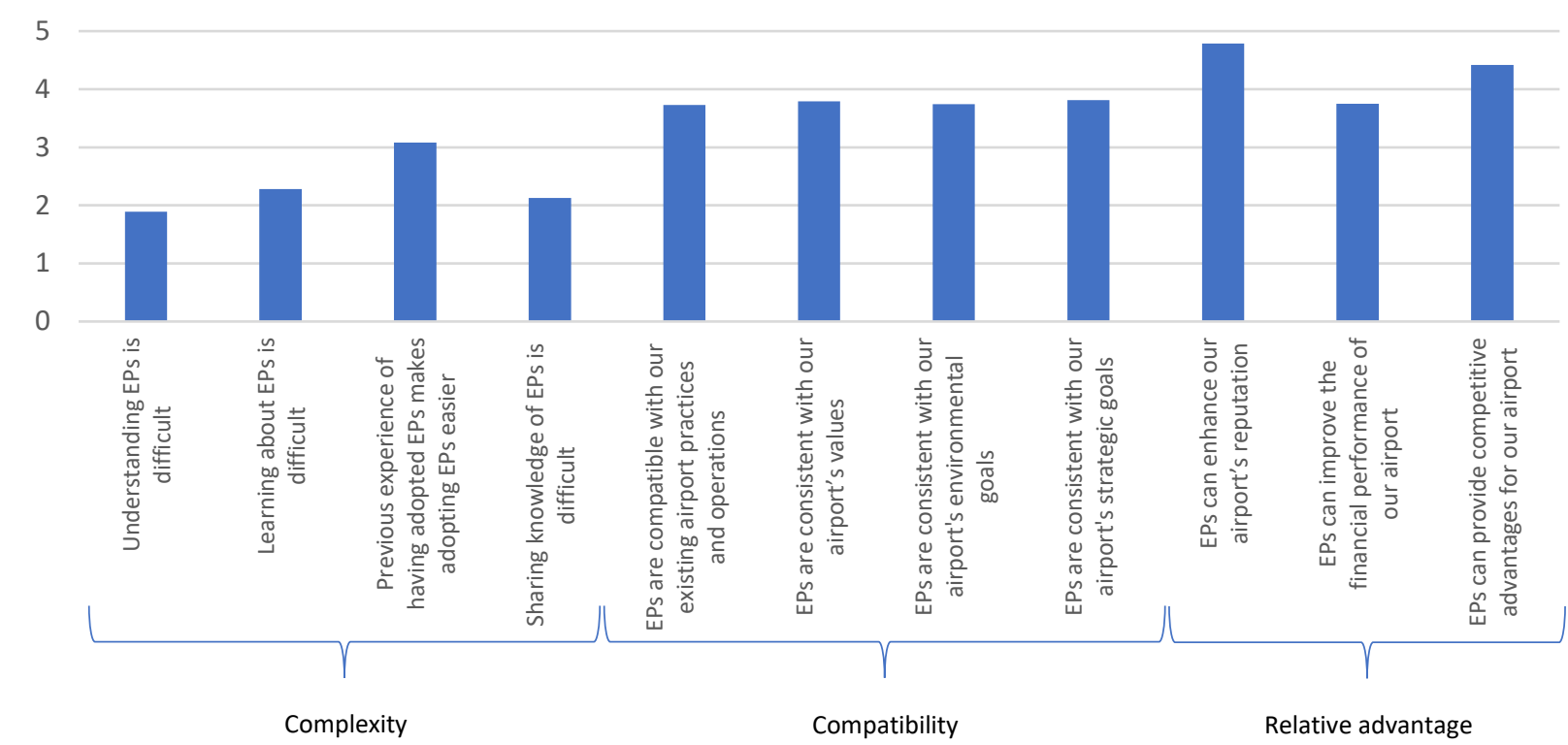

Figure 7 Technological context: mean statement responses

Broadly speaking, respondents did not perceive EPs as being complex and challenging to learn and engage with. However, the regression analysis (discussed in section 4.4.4) revealed that where respondents did perceive practices to be complex, they were less likely to adopt EPs. The results corroborate the work of Hillary (2004), Simpson et al. (2004), Lee (2009) and Weng and Lin (2011) who suggest that increased perceived complexity results in reduced practice adoption, however the responses contradict their suggestions that smaller organisations feel that EPs are too complex and

\footnotetext{
${ }^{8}$ The spread of responses to the statements ranged from 1 (strongly disagree) to 5 (strongly agree.)
} 
challenging to adopt. In order to further encourage EP engagement, practice complexities should be kept to a minimum, as adoption is less likely when perceived complexity increases.

Over $40 \%$ of airports indicated that they felt that adopting practices is easier when coupled with previous experience. This supports Upham and Mills (2005), who suggested that exposure to best practice and success stories makes adoption more likely. Increased networking and experience showcasing opportunities would likely be the most effective approach to this, as 'airports rely on peer group learning for their most critical decision making' and, furthermore, the literature has suggested that the dissemination of 'guidebook' type materials has been ineffective (ACRP, 2011, 2016; Ryerson, 2016, p. 1).

The majority of respondents agreed that EPs are compatible with existing operations, corporate values, and environmental and strategic goals. However, very few strongly agreed with these statements. Even in the case of practices being compatible with the environmental goals of the airports, fewer than $14 \%$ strongly agreed with the statement. This suggests that additional research is required to establish what small airport strategic and environmental goals are, in order to design EPs which best align with them. strongly agreed that the practices could enhance their airport's reputation. This was not anticipated, as extant literature generally focuses on the social benefits brought about by small airports, providing connecting services to comparatively isolated communities. Chassé and Boiral, (2016) suggest that small organisations' environmental impacts are often overlooked, excused by the social benefits they bring, thus it was not expected that the airports would feel there was reputational advantage to be gained by appearing to be 'environmentally friendly'. It would likely be effective to further highlight the advantages which can be elicited from EPs to drive practice engagement. 


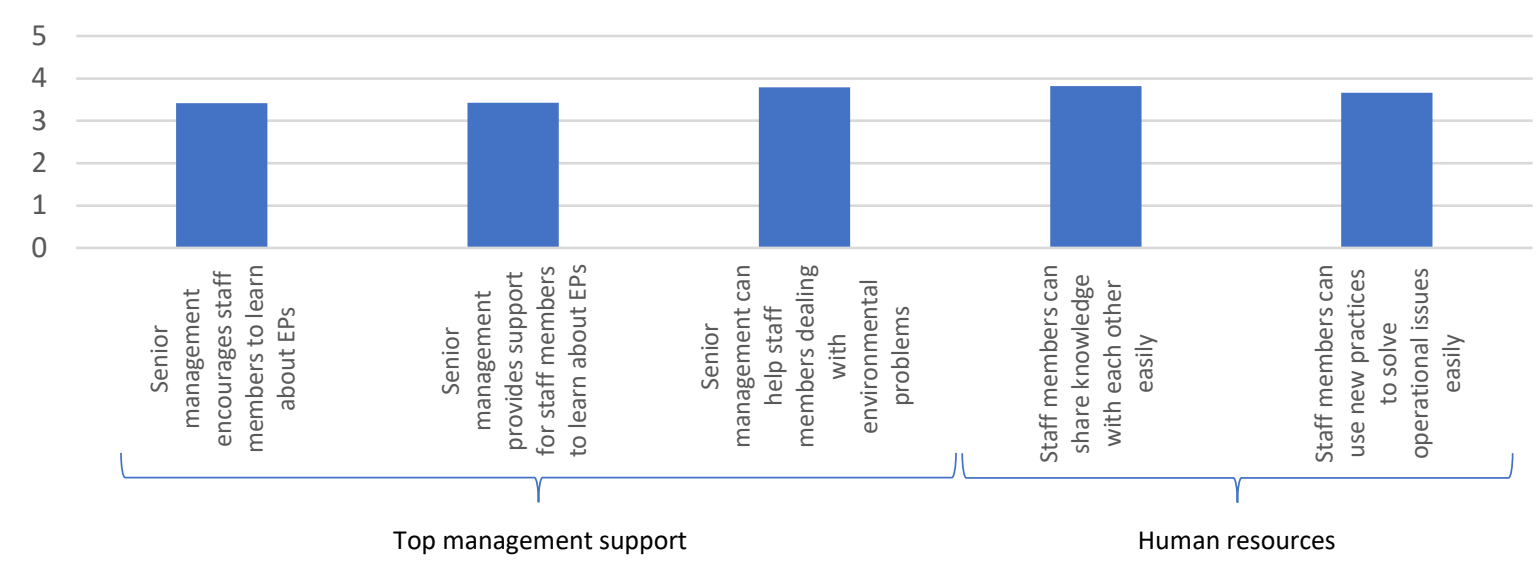

Figure 8 Organisational context: mean statement responses

404

405

406

407

Figure 8 presents the mean response to the individual statements relating to organisational context.

Generally, support provided by top management in the pursuit of EPs is present. However, the regression analysis did not find the relationship between top management support and adoption to be significant. This disagrees with conclusions drawn by Jenkins, (2006), Walker et al., (2008) and Lee, (2009) however corroborates similar findings from Ramakrishnan et al., (2015), suggesting that, while beneficial, top management support is not a vital factor for adopting EPs in this context.

For human resources, respondents indicated that they generally agreed with the provided statements and the regression analysis found the relationship to be significant. This agrees with results from Lin and Ho, $(2008,2011)$ and Weng and Lin, $(2011)$ who also found the relationship to be significant. However, in previous studies, the relationship between human resources and EP adoption has not been negative when included in a regression model. Further investigation would be required to explore the effect of confounding variables.

Airport size also has a significant relationship with EP adoption, suggesting that bigger airports are more likely to adopt practices. However, the beta weight of this variable was not large, and other variables provided much stronger weightings. This suggests that while size may play a role in affecting adoption, it does not play as significant a role as is suggested in other studies (Cassells and Lewis, 2011; Agan et al., 2013; Hoogendoorn et al., 2015). 


\subsubsection{Environmental context}

422 Figure 9 displays the mean response to the individual statements in the survey relating to the environmental context.

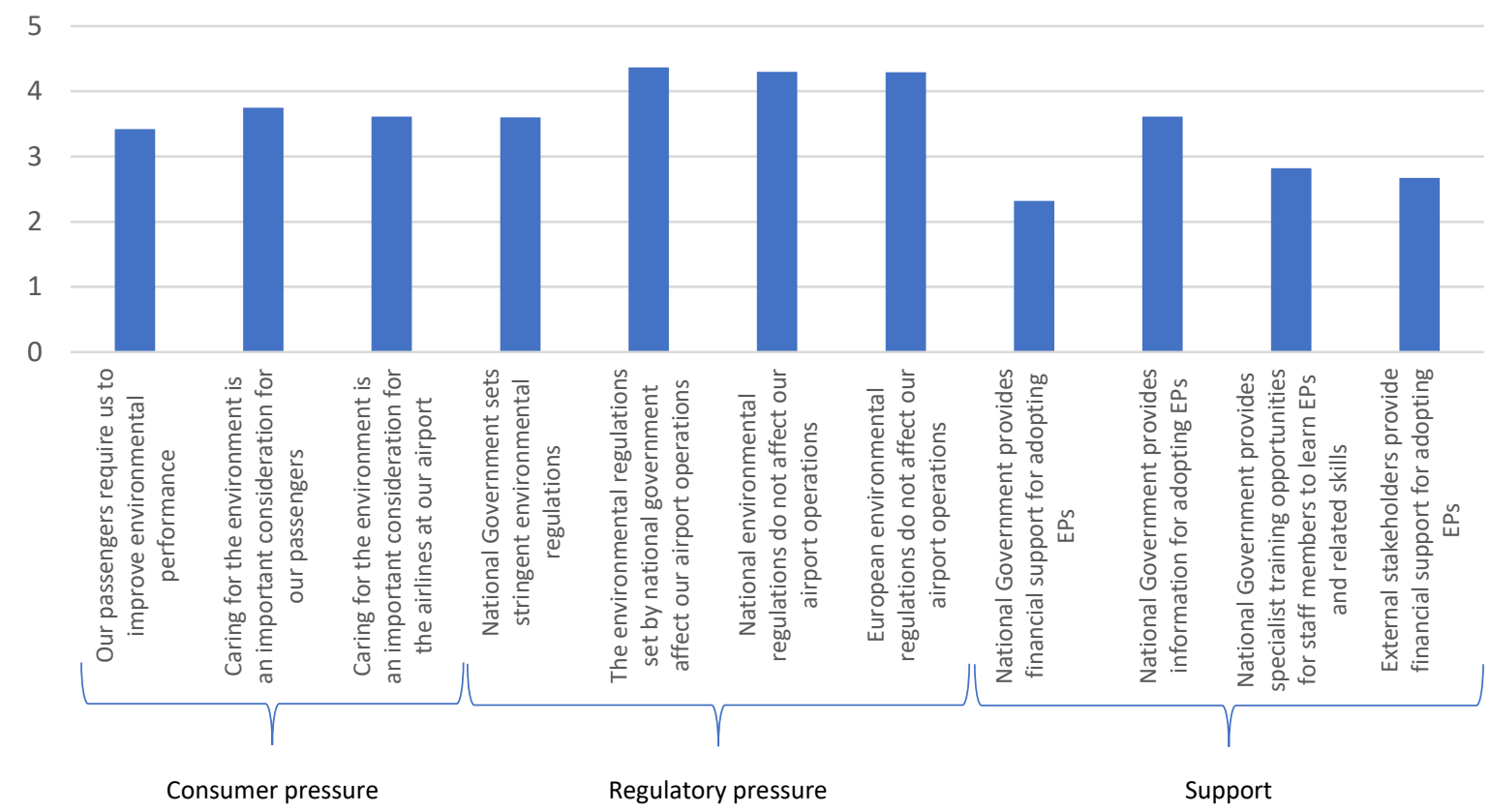

Figure 9 Environmental context: mean statement responses

The regression analysis (Section 4.4.4) revealed consumer pressure to have the largest beta weighting relating to EP adoption, suggesting that the greater the perceived pressure from consumers the more likely small airports are to adopt. Respondents expressing that they generally felt that consumers demanded environmental performance improvement largely disagrees with Hillary (2004) and Gadenne et al. (2009) who claimed that pressures of this kind are not felt by smaller organisations. However, this result does agree with Darnall et al. (2010), who said that when smaller organisations recognise consumer pressures, they are usually responsive.

Regulatory pressure was found to have the second highest beta weight in the regression analysis. Respondents indicated that they felt that both national and European regulations impacted their operations. Regulatory pressure perceptions were also the only factor found to significantly vary ${ }^{9}$ by

\footnotetext{
${ }^{9}$ Using independent samples t-tests.
} 

geographical location. Airports in Northern Europe had a statistically larger average overall response to regulatory pressure, compared to the other European regions (see Figure 10). 


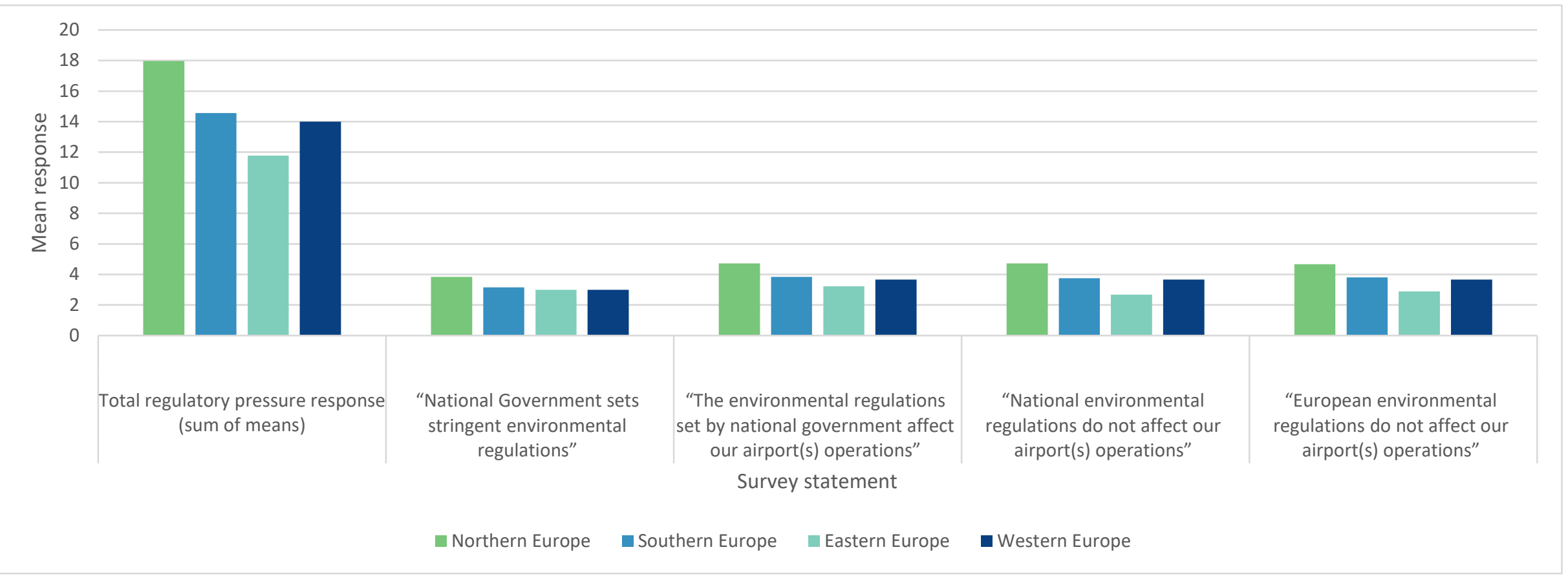

436

Figure 10 Mean responses to regulatory pressure split by geographic region 
This geographical variation in perceptions warrants further investigation to potentially identify best regulatory practices to employ in other regions. The results in the analysis do, however, largely contradict much existing literature (Revell and Blackburn, 2007; Brammer et al., 2012; Agan et al., 2013) which suggests that regulation at small organisations is either ineffective or unpoliced. This research would suggest that regulation is effective and is encouraging engagement with EPs.

While support was not found to be significant in the regression analysis and had an unexpected negative relationship with EP (something which, in itself, warrants further investigation) the trends shown in responses to the statements provide valuable insight. The majority of airports reported that they did not feel that their governments provided sufficient financial support to assist in the pursuit of EPs; they did, however, agree that support in the form of information is provided. The majority of respondents neither agreed nor disagreed with the final two statements. This suggests that perhaps there is an opportunity to be exploited in which specialist training can be provided to small airports to assist in the adoption of EPs and also that external stakeholders can provide additional support.

From Northern European airports, the mean overall response to support was larger than the responses from the other European regions. There is potential that with the greater regulatory pressure exuded from national bodies in Northern Europe comes greater support. This, again, is worthy of further investigation.

\subsubsection{Regression analysis} To explore the relationships between the nine factors (discussed in section 4 of the survey) and EP adoption at small airports, an OLS regression was conducted. OLS regression was appropriate as the dependant variable was continuous and the assumptions of multicollinearity, normality and homoscedasticity were met. dependant variable $(D V)($ mean $=22.32 ; S D=6.339)$. The total extent of adoption was calculated by 
summing the self-reported extent of EP adoption across the eight environmental target areas

468 (indicated on a $1-5$ Likert scale,) as discussed in section 3. As such, it is assumed that all environmental target areas are of equal importance. The total extent of adoption is therefore an indicative measure of the relative importance an airport operator places on integrating environmental management within their operations. The minimum possible value of the DV was eight (indicating that the respondent airport was not at all engaged with any of the target areas,) and the maximum possible value of the DV was 40 (indicating that the reporting airport was engaged to a great extent with all target areas.) Table 5 shows the results of the regression analysis.

Table 5 Regression analysis

\begin{tabular}{|c|c|c|c|}
\hline \multirow[b]{2}{*}{ Model } & \multicolumn{2}{|c|}{ Standardized Coefficients } & \multirow[b]{2}{*}{ VIF } \\
\hline & Beta $^{10}$ & $\mathbf{t}$ & \\
\hline (Constant) & & 65.667 & \\
\hline Compatibility & .093 & 1.063 & 3.551 \\
\hline Complexity & $-.191^{*}$ & -2.855 & 2.071 \\
\hline Relative advantage & $-.141^{*}$ & -2.289 & 1.761 \\
\hline Top management support & .176 & 1.977 & 3.681 \\
\hline Human resources & $-.171^{*}$ & -3.083 & 1.418 \\
\hline Size & $.186 * *$ & 3.904 & 1.049 \\
\hline Regulatory pressure & $.394^{* *}$ & 5.265 & 2.591 \\
\hline Consumer pressure & $.446^{* *}$ & 6.169 & 2.422 \\
\hline Support & -.145 & -1.928 & 2.618 \\
\hline$N=109$ & $\mathrm{R}^{2}=$ & & \\
\hline
\end{tabular}

476

$10 *$ and $* *$ indicates significance at the $95 \%$ and $99 \%$ level, respectively. 
The results found that compatibility, senior management support, airport size, regulatory pressure and consumer pressure have a positive relationship with EP adoption, while complexity, relative advantage, human resources and support have a negative relationship.

The analysis indicates that increased perceptions of consumer pressure, regulatory pressure and larger airport sizes will likely result in airports being more engaged with EPs. It also indicates that the more complex airports perceive EPs to be, the less likely they are to adopt them. This analysis also suggests that an increase in perceived relative advantage and the quality of human resources results in reduced engagement. When taken as standalone independent variables, both have a positive association with EP adoption, however when other variables are added to the model the association becomes negative (the same applies to support however this variable was not found to be significant.) It is anticipated that this is the result of confounding variables and requires further investigation.

This research has provided new insights into the current environmental behaviours of small European airports. It has shown that there are some types of EPs which are more and less favoured by small airports, and target areas to which small airports are more and less committed to. Importantly, EP adoption by small airports is identified as being different from larger airports. human resources and relative advantage were identified as having significant impacts on the likelihood of airports adopting EPs. Existing literature on small organisation adoption of EPs focuses on the limitations small size can impose on the adoption process. The results here show that for aviation, size may have an impact, however other factors have a more substantive effect on EP adoption. Therefore, it is necessary to target more specifically these other factors to further encourage EP adoption amongst small airports. 
The environmental and technological contexts, which were identified thorough the TOE framework, have a greater effect than the organisational context on EP adoption. Therefore, it is recommended that airlines, passengers and regulatory bodies continue to demand environmental behaviour from airports and that exceptions and exclusions are not be made based on size alone. This should be coupled with increased networking and showcasing opportunities and support where required, specifically in the form of specialist staff training. With this being said, however, it is now also important to consider the impact of the COVID-19 pandemic on future small airport engagement with EPs. Although great uncertainty surrounds the realistic impact on the aviation industry and how industry recovery will look, it is likely that airports, particularly smaller airports, will see decreased revenues and compounded financial challenges. This will likely exacerbate resource issues at small airports, limiting their ability to engage with EPs. Furthermore, with decreased demand for air travel, the environmental impact of airports will also decrease, lessening the imminent need to address environmental externalities.

514 This paper makes several important contributions by adding to the limited field of study focusing on small airports, specifically focusing on their environmental behaviours and the factors affecting this behaviour. The research has revealed that some of the claims in the existing literature regarding EP adoption at airports do not necessarily hold true in the context of small European airports. This, therefore, has the potential to more effectively inform policy. Existing aviation environmental

519 policies, guided by existing literature, have been primarily based on information relevant to larger 520 airports; this study's contribution will allow more appropriate and effective environmental policies 521 to be designed for small airports. The exploration of environmental target areas and employed practice types in this study builds on the previously conducted ACRP studies (ACRP, 2016, 2008), however adds to the literature by examining a new geographic area, subject to different regulatory regimes and operational 
525 boundaries. Whereas ACRP $\left(2016,2008^{11}\right)$ examined only small airports in the United States, this

526 research has provided the first examination of the European airport industry and examined small

527 airports spanning across 36 different countries. Furthermore, while the ACRP studies had examined

528 the influence of various drivers and barriers to EP engagement, they had not considered the role

529 that airport ownership plays. This study's examination of this factor presents a further development

530 of the previous work. In addition to presenting the first large scale, European based survey of small

531 airports, this research also presents the first application of the TOE framework and regression in an

532 aviation context. Further research is required to explore and confirm the patterns and trends of

533 practice adoption found in this study. This should in particular focus on examining further the causal

534 relationships indicated in this study and understanding why certain environmental target areas were

535 prioritised over others.

536 Furthermore, the classifying of airports by EP engagement level and exploring the features of the

537 identified groups presents an additional contribution. Combining the segmented EP engagement

538 groups with the novel identification of factors affecting EP adoption can assist in the encouraging of

539 EP engagement.

540 The research may be valuable to small airport managers and national and international regulatory

541 bodies. Identifying current trends in EP adoption and segmenting airports by EP engagement allows

542 managers to place their airport's activities in the identified engagement groups for benchmarking

543 purposes. Suggesting factors to further encourage EP engagement can assist policy makers in the

544 design of new practices, packages and policies to increase adoption and reduce or mitigate the

545 environmental impact of airport operations and future growth.

5466 References

547 ACl-Europe (2009a) Airport Carbon Accreditation - Welcome to the Airport Carbon Accreditation

${ }^{11}$ ACRP (2008) did include 21 airports from outside of the United States, however their size was not specified. 
ACl-Europe (2009b) Airport Carbon Accreditation - What is it? Available from

ACl-Europe (2018) Airport Traffic Report Available from https://www.aci-europe.org/media-roomairport-traffic-report/member.html [accessed 10 July 2018].

ACl-Europe (2016) The Ownership of Europe's Airports.

ACI-NA (n.d.) Going Greener - Minimizing airport environmental impacts. Washington DC: .

ACRP (2011) ACRP Report 43: Guidebook of Practices for Improving Environmental Performance at Small Airports. Washington DC: .

ACRP (2012) ACRP Report 80: Guidebook for Incorporating Sustainability into Traditional Airport Projects. Washington DC: .

ACRP (2008) ACRP Synthesis 10: Airport Sustainability Practices. Washington DC: .

ACRP (2010) ACRP Synthesis 21: Airport Energy Efficiency and Cost Reduction. Washington DC: .

ACRP (2015) ACRP Synthesis 66: Lessons Learned from Airport Sustainability Plans. Washington DC: .

ACRP (2016) ACRP Synthesis 69: Airport Sustainability Practices - Drivers and Outcomes for Small Commercial and General Aviation Airports. Washington DC: .

ACRP (2018) ACRP Synthesis 92: Airport Waste Management and Recycling Practices. Washington DC: .

AEF (2016) New report finds aircraft noise policy puts the health of over one million people at risk Available from https://www.aef.org.uk/2016/01/12/new-report-finds-aircraft-noise-policiesput-the-health-of-over-one-million-people-at-risk/ [accessed 22 July 2019]. 
Agan, Y., Acar, M.F. and Borodin, A. (2013) Drivers of environmental processes and their impact on performance: a study of Turkish SMEs. Journal of Cleaner Production, 51 23-33.

573

574

575

576

577

578

579

580

581

582

583

584

585

586

587

588

589

590

591

592

Angeles, R. (2013) Using the Technology-Organization-Environment Framework and Zuboff's Concepts for Understanding Environmental Sustainability and RFID: Two Case Studies. World Academy of Science, Engineering and Technology International Journal of Economics and Management Engineering, 7(11) 2878-2887.

Angeles, R. (2014) Using the Technology-Organization-Environment Framework for Analyzing Nike's "Considered Index" Green Initiative, a Decision Support System-Driven System. Journal of Management and Sustainability, 4(1) 96-113.

ANNA.AERO (2019) Databases Available from https://www.anna.aero/databases/ [accessed 29 July 2019].

Armstrong, S.J. and Overton, M.T.S. (1977) Estimating nonresponse bias in mail surveys. Journal of Marketing Research, 14(3) 396-402.

Ashford, N., Stanton, H.P.M., Moore, C.A., Coutu, P. and Beasley, J.R. (2013) Airport operations. 3rd edition. McGraw-Hill.

Awa, H.O., Ukoha, O. and Igwe, S.R. (2017) Revisiting technology-organization-environment (T-O-E) theory for enriched applicability. The Bottom Line, 30(1) 2-22.

Baker, J. (2011) The technology-organization-environment framework. In: Y.K. Dwivedi et al. (ed.) Information Systems Theory: Explaining and Predicting Our Digital Society, Vol. 1. New York: Springer, 231-246.

Berisha, G. and Pula, J.S. (2015) Defining Small and Medium Enterprises a critical review. Academic Journal of Business, Administration, Law and Social Sciences, 1(1) 17-28. 
Boiral, O., Ebrahimi, M., Kuyken, K. and Talbot, D. (2017) Greening Remote SMEs: The Case of Small Regional Airports. Journal of Business Ethics, 1-15.

Brammer, S., Hoejmose, S. and Marchant, K. (2012) Environmental Management in SMEs in the UK: Practices, Pressures and Perceived Benefits. Business Strategy and the Environment, 21(7) 423434.

Budd, T., Budd, L. and Ison, S. (2015) Environmentally sustainable practices at UK airports. Proceedings of the ICE-Transport, 168(2) 116-123.

CAA (2017a) Airport data 2017 Available from https://www.caa.co.uk/Data-and-analysis/UKaviation-market/Airports/Datasets/UK-Airport-data/Airport-data-2017/ [accessed 15 January 2019].

CAA (2017b) Information on aviation's environmental impact. West Sussex: .

Cassells, S. and Lewis, K. (2011) SMEs and environmental responsibility: Do actions reflect attitudes? Corporate Social Responsibility and Environmental Management, 18(3) 186-199.

Chan, E.S.W. (2011) Implementing Environmental Management Systems in Small-And Medium-Sized Hotels: Obstacles. Journal of Hospitality \& Tourism Research, 35(1) 3-23.

Chassé, S. and Boiral, O. (2016) Legitimizing Corporate (Un) Sustainability: A Case Study of Passive SMEs. Organization \& Environment, 1-22.

Couto, E. de A. do, Calijuri, M.L., Assemany, P.P., Santiago, A. da F. and Lopes, L.S. (2015) Greywater treatment in airports using anaerobic filter followed by UV disinfection: an efficient and low cost alternative. Journal of Cleaner Production, 106 372-379.

D'Souza, C. and Taghian, M. (2018) Small and medium size firm's marketing competitive advantage and environmental initiatives in the Middle East. Journal of Strategic Marketing, 26(7) 568582. 
Daley, B. (2010) Air Transport and the Environment. 1st edition. London: Routledge.

617 Darnall, N., Henriques, I. and Sadorsky, P. (2010) Adopting proactive environmental strategy: The influence of stakeholders and firm size. Journal of Management Studies, 47(6) 1072-1094.

619

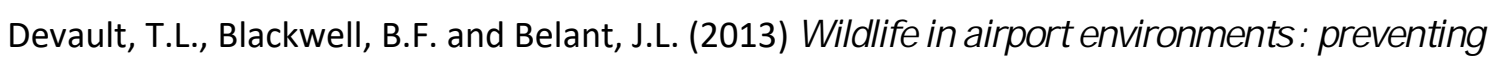
animal-aircraft collisions through science-based management. The John Hopkins University Press (ed.). JHU Press.

Devault, T.L., Kubel, J., Rhodes Jr, O.E., Dolbeer, R. and Jr, O.E. (2009) Habitat and Bird Communities at Small Airports in the Midwestern USA. In: 13th Wildlife Damage Management Conference. 2009 137-145.

Dimitriou, D.J. and Voskaki, A.J. (2010) Regional airports' environmental management: key messages from the evaluation of ten European airports. International Journal of Sustainable Development and Planning, 5(2) 150-162.

Donehue, P. and Baker, D. (2012) Remote, rural, and regional airports in Australia. Transport Policy, $24232-239$.

EASA (2019) Executive Summary / European Aviation Environmental Report Available from https://www.easa.europa.eu/eaer/executive-summary [accessed 17 July 2019].

European Commission (2019) International Aviation: ECAA.

European Union (2002) EUR-Lex - 32002L0049 - EN - EUR-Lex. EUR-Lex.

FAA (2019) Passenger Boarding (Enplanement) and All-Cargo Data for U.S. Airports Available from https://www.faa.gov/airports/planning_capacity/passenger_allcargo_stats/passenger/ [accessed 29 July 2019].

Gadenne, D.L., Kennedy, J. and Mckeiver, C. (2009) An Empirical Study of Environmental Awareness and Practices in SMEs. Journal of Business Ethics, 84 45-63. 
Graham, A. (2018) Managing airports: an international perspective. 5th edition. Routledge.

640

641

642

643

644

645

646

647

648

649

650

651

652

653

654

655

656

657

658

659

660

661

Graham, A. (2013) The Environmental Impact of Airports. In: Managing Airports. 4th edition London: Routledge, 286-308.

Grampella, M., Martini, G., Scotti, D., Tassan, F. and Zambon, G. (2017) Determinants of airports' environmental effects. Transportation Research Part D: Transport and Environment, 50 327344.

Gudmundsson, S.V. (2018) European Air Transport Regulation: Achievements and Future Challenges. Toulouse: .

Gupta, H. and Barua, M.K. (2018) A framework to overcome barriers to green innovation in SMEs using BWM and Fuzzy TOPSIS. Science of The Total Environment, 633 122-139.

Hansen, M., Ryerson, M. and Marchi, R. (2013) New Methodologies for Airport Environmental Impact Analysis. In: K Zografos, G Andreatta, A Odoni (eds.) Modelling and Managing Airport Performance. Chichester: , 145-169.

Hartsfield-Jackson Atlanta International Airport (2019) GreeningATL Available from https://www.atl.com/community/sustainability/ [accessed 29 July 2019].

Hillary, R. (2004) Environmental management systems and the smaller enterprise. Journal of Cleaner Production, 12 561-569.

Hoogendoorn, B., Guerra, D. and van der Zwan, P. (2015) What drives environmental practices of SMEs? Small Business Economics, 44(4) 759-781.

Hörisch, J., Johnson, M.P. and Schaltegger, S. (2015) Implementation of Sustainability Management and Company Size: A Knowledge-Based View. Business Strategy and the Environment, 24(8) 765-779.

Hwang, B.-N., Huang, C.-Y. and Wu, C.-H. (2016) A TOE Approach to Establish a Green Supply Chain 
Jaiyeola, A.T. (2017) The management and treatment of airport rainwater in a water-scarce environment. International Journal of Environmental Science and Technology, 14(2).

665

666

667

668

669

670

671

672

673

674

675

676

677

Jayanti, R.K. and Rajeev Gowda, M.V. (2014) Sustainability dilemmas in emerging economies. IIMB Management Review, 26(2) 130-142.

Koç, S. and Durmaz, V. (2015) Airport Corporate Sustainability: An Analysis of Indicators Reported in the Sustainability Practices. Procedia - Social and Behavioral Sciences, 181 158-170.

Kousar, S., Sabri, P., Zafar, M. and Akhtar, A. (2017) Technological Factors and Adoption of Green Innovation-Moderating Role of Government Intervention: A Case of SMEs in Pakistan. Pakistan Journal of Commerce and Social Sciences, 11(3) 833-861.

Kuan, K.K.Y. and Chau, P.Y.K. (2001) A perception-based model for EDI adoption in small businesses using a technology-organization-environment framework. Information \& Management, 38(8) 507-521.

Kuan, K.K.Y.Y. and Chau, P.Y.K.K. (2001) A perception-based model for EDI adoption in small businesses using a technology-organization-environment framework. Information and Management , 38(8) 507-521.

Lee, K.-H. (2009) Why and how to adopt green management into business organizations?: The case study of Korean SMEs in manufacturing industry. Management Decision, 47(7) 1101-1121.

Lin, C.-Y. and Ho, Y.-H. (2008) An Empirical Study on Logistics Service Providers' Intention to Adopt Green Innovations. Journal of Technology Management \& Innovation, 3(1) 17-26.

Lin, C.-Y. and Ho, Y.-H. (2011) Determinants of Green Practice Adoption for Logistics Companies in China. Journal of Business Ethics, 98(1) 67-83.

Lippert, S.K. and Govindarajulu, C. (2006) Technological, Organizational, and Environmental 
Luther, L. (2007) Environmental Impacts of Airport Operations, Maintenance, and Expansion.

687 Washington DC: .

Macpherson, A. and Wilson, A. (2003) Enhancing SMEs' capability: opportunities in supply chain relationships? Journal of Small Business and Enterprise Development, 10(2) 167-179.

Martin, J.A., Conkling, T.J., Belant, J.L., Biondi, K.M., Blackwell, B.F., Devault, T.L., Fernandez -Juric, E., 691 Schmidt, P.M. and Seamans, T.W. (2013) Wildlife Conservation and Alternative Land Uses at Airports.

Monsalud, A., Ho, D. and Rakas, J. (2014) Greenhouse gas emissions mitigation strategies within the airport sustainability evaluation process. Sustainable Cities and Society, 14 414-424.

Montabon, F., Sroufe, R. and Narasimhan, R. (2007) An examination of corporate reporting, environmental management practices and firm performance. Journal of Operations

Netjasov, F. (2012) Contemporary measures for noise reduction in airport surroundings. Applied Acoustics, 73(10) 1076-1085.

Pitt, M., Brown, A. and Smith, A. (2002) Waste management at airports. Facilities, 20(5/6) 198-207. behavioral research: A critical review of the literature and recommended remedies. Journal of Applied Psychology, 88(5) 879-903. 
For Small And Medium Enterprises (Smes) In MalaysiaFactors Influencing Green Purchasing Adoption For Small And Medium Enterprises (SMEs) In Malaysia. International Journal of Business and Society, 16(1) 39-56.

Ramdani, B., Chevers, D. and Williams, D.A. (2013) Predicting SMEs' adoption of enterprise systems. Journal of Small Business and Enterprise Development, 20(4) 735-753.

Ratliff, G., Sequeira, C., Waitz, I., Ohsfeldt, M., Thrasher, T., Graham, M. and Thompson, T. (2009) Aircraft Impacts on Local and Regional Air Quality in the United States. Massachusetts: .

Revell, A. and Blackburn, R. (2007) The business case for sustainability? An examination of small firms in the UK's construction and restaurant sectors. Business Strategy and the Environment, 16(6) 404-420.

Roberts, P. and Priest, H. (2006) Reliability and validity in research. Nursing Standard, 20(44) 41-46.

Roberts-Hughes, R. (2014) Sustainable Airports: Improving the environmental impact of the UK's global gateways.

Rodríguez-Díaz, A., Adenso-Díaz, B. and González-Torre, P.L. (2017) A review of the impact of noise restrictions at airports. Transportation Research Part D: Transport and Environment, 50 144153.

Ruslan, M.F., Senin, A.A. and Soehod, K. (2014) Technological Determinants of Green Production Adoption by Malaysian Small and Medium Enterprises (SMEs): A Conceptual Framework. In: nternational Conference on Business, Management \& Corporate Social Responsibility. 2014 Batam, Indonesia: , 59-63.

Ryerson, M.S. (2016) Building Air Service Sustainability: Analytical Approach to Documenting Air Carrier Incentive Programs in Airport Sustainability Plans. Transportation Research Record: Journal of the Transportation Research Board, 2569(1) 1-15. 
Sameh, M.M. and Scavuzzi, J. (2016) Environmental Sustainability Measures for Airports. Occasional Paper Series.

Simpson, M., Taylor, N. and Barker, K. (2004) Environmental responsibility in SMEs: Does it deliver competitive advantage? Business Strategy and the Environment, 13(3) 156-171.

Sroufe, R. (2009) Effects of Environmental Management Systems on Environmental Management Practices and Operations. Production and Operations Management, 12(3) 416-431.

Tavakol, M. and Dennick, R. (2011) Making sense of Cronbach's alpha. International Journal of Medical Education, 2 53-55.

The World Bank (2017) Population density (people per sq. km of land area) Available from https://data.worldbank.org/indicator/EN.POP.DNST [accessed 17 June 2019].

Tornatzky, L. and Fleischer, M. (1990) The processes of technological innovation. Vol. 16. Lexington Mass.: Lexington Books.

UK Trade and Investment (2013) Sustainable airports: Benefiting from the UK's world-class expertise.

United Nations (2020) UNSD - Methodology Available from https://unstats.un.org/unsd/methodology/m49/ [accessed 27 January 2020].

Wang, Y.-M., Wang, Y.-S. and Yang, Y.-F. (2010) Understanding the determinants of RFID adoption in the manufacturing industry. Technological Forecasting and Social Change, 77(5) 803-815.

Weng, M.-H. and Lin, C.-Y. (2011) Determinants of green innovation adoption for small and mediumsize enterprises (SMES). African Journal of Business Management, 5(22) 9154-9163.

Williams, B., Onsman, A. and Brown, T. (2010) Exploratory factor analysis: A five-step guide for novices. Journal of Emergency Primary Health Care , 8(3) 1-13.

Wolfe, P.J., Yim, S.H.L.L., Lee, G., Ashok, A., Barrett, S.R.H.H. and Waitz, I.A. (2014) Near-airport distribution of the environmental costs of aviation. Transport Policy journal, 34 102-108. 
754 Wright, K.B. (2005) Researching Internet-Based Populations: Advantages and Disadvantages of

755 Online Survey Research, Online Questionnaire Authoring Software Packages, and Web Survey

756 Services. Journal of Computer-Mediated Communication, 10(3).

757 Your Heathrow (2018) Heathrow 2.0 Available from https://your.heathrow.com/heathrow-2-0/

$758 \quad$ [accessed 26 September 2018].

759

760 Acknowledgements

761 The authors would like to thank the Editor and the reviewers for their very helpful comments on an

762 earlier draft of this paper. 